\title{
Decline of recruitment success in cockles and other bivalves in the Wadden Sea: possible role of climate change, predation on postlarvae and fisheries
}

\author{
J. J. Beukema*, R. Dekker \\ Royal Netherlands Institute for Sea Research, PO Box 59, 1790AB Den Burg, Texel, The Netherlands
}

\begin{abstract}
In the last $~ 15 \mathrm{yr}$, frequent recruitment failures in the main bivalve species in the western Wadden Sea led to insufficient food supply for some specialised bird species, sharpening conflicts between nature conservationists and fishermen. To study possible causes of the recent recruitment failure in bivalves, we compare long-term data sets (1973 to 2002) of annual abundance of spat of 3 of the most important species of bivalves (cockle Cerastoderma edule, gaper clam Mya arenaria, and Baltic tellin Macoma balthica) on Balgzand, a tidal-flat area in the westernmost part of the Wadden Sea. In the 3 species, recruitment success declined significantly over the period of observation, particularly at offshore sampling sites which were characterized by low intertidal levels and sandy sediments. In these areas, we found high biomass values of a predator of bivalve postlarvae, the shrimp Crangon crangon. In each of the 3 bivalve species, annual recruitment (estimated as numerical density of spat in August) in these areas was negatively related to shrimp biomass at the time of settlement of postlarvae (May/June). Shrimp biomass has increased over the last $\sim 30$ yr. High near-shore flats showed invariably low shrimp biomass values and appear to serve as a refuge for postlarval bivalves in years of high predation pressure. Only in this coastal part of Balgzand was no decline in bivalve recruitment found; in fact, cockle recruitment even increased. Alternative explanations for the observed changes in recruitment of bivalves are discussed, including changes in sediment composition and bottom-disturbing fishing for cockles, mussels and lugworms. It is concluded that the recruitment trends on Balgzand (and other parts of the Wadden Sea) are governed primarily by natural processes, in particular increases in predation pressure on early benthic stages, which in turn appears to be largely governed by the warming climate.
\end{abstract}

KEY WORDS: Epibenthic predators - Crangon crangon - Cerastoderma edule - Macoma balthica · Mya arenaria $\cdot$ Tidal flats $\cdot$ Fishery disturbance $\cdot$ Sediment composition

\section{INTRODUCTION}

In coastal areas, the annual recruitment of bivalves is characterized by substantial year-to-year variability; failing and successful cohorts often differ by orders of magnitude in species such as cockles Cerastoderma edule, mussels Mytilus edulis, gaper clams Mya arenaria and Baltic tellins Macoma balthica (Beukema 1982, Möller \& Rosenberg 1983, Möller 1986, Bachelet 1986, Desprez et al. 1991, Ducrotoy et al. 1991, Beukema et al. 2001a, Strasser et al. 2001, 2003). The consequences of such variability in the abundance of early-benthic stages are far-reaching, e.g. explaining most of the subsequent between-year variability in numerical abundance, biomass and production of these species (Möller \& Rosenberg 1983, Coosen et al. 1994, Beukema \& Cadée 1999, Beukema et al. 2001a, Van der Meer et al. 2001). As bivalves account for a substantial share of the total biomass and production in most coastal areas, the variability in their abundance (e.g. Beukema et al. 1993) also affects their consumers, including human fisheries. Conflicts between shellfish fisheries and nature conservation are particularly sharp in years with low stocks of cockles and mussels, which occur after several years of low recruitment and ongoing fishery harvest (for an example see Beukema \& Cadée (1996)). In such years, bivalve-eating birds may die from starvation, e.g. oystercatchers Haematopus ostralegus (Camphuysen et al. 1996), eiders Somateria mollissima (Camphuysen et al. 2002), eiders and 
oystercatchers (Smit et al. 1998), oystercatchers and knot Calidris canutus (Atkinson et al. 2003).

In the last $15 \mathrm{yr}$, cockle stocks in the Dutch Wadden Sea have shown a declining trend and protests against cockle fishery have increased. We think that the primary cause of these problems is that failures of bivalve recruitment have become more frequent. It is, then, urgent that we obtain more knowledge on the variability of bivalve recruitment success in this area, its trends, and its possible causes. Major questions include whether recruitment is governed mostly by natural factors, such as the occurrence of severe winters (Beukema et al. 2001a), or year-to-year variability in predation pressure on early life stages (Beukema et al. 1998, Philippart et al. 2003), and whether the ongoing shellfish fishery is also a decisive factor because of mechanical dredging causing serious and long-lasting bottom disturbance that may have long-term negative consequences for bivalve recruitment (Piersma et al. 2001). Answers to such questions are relevant for Wadden Sea management and are of current interest as part of the evaluation of the present Dutch fishery politics and a possible continuation of mechanical cockle fishery in the Dutch Wadden Sea (Ens 2003, Ens et al. 2004).

A substantial part of bivalve recruitment variability appears to be climate related (Beukema 1992b, Young et al. 1996, Beukema et al. 2001a, Philippart et al. 2003). In several bivalve species in the Wadden Sea, including Cerastoderma edule, Mytilus edulis, Mya arenaria and Macoma balthica, better recruitment has generally been observed after cold rather than after mild winters (Beukema 1992b, Beukema et al. 1998, Beukema et al. 2001a, Strasser et al. 2001, 2003, and references therein). As in many parts of the world, temperatures in the Wadden Sea area have risen during recent decades (Van Aken 2003). Warmer-thanaverage winter and spring periods in the Wadden Sea were especially frequent after 1987 (see e.g. Fig. 1f of Beukema et al. 2001a for winter temperatures, and Fig. 3a of Philippart et al. 2003 for spring temperatures). In accordance with the negative relationship between winter temperatures and subsequent recruitment success, recruitment in all of the above-mentioned bivalve species was generally lower after 1987 than in the earlier part of the 1980s and in the 1970s. This was also the case in other Dutch, German and Danish areas of the Wadden Sea (Strasser et al. 2003).

The mechanism behind the influence of winter severity on recruitment success is only partly known, and most studies are limited to Macoma balthica. Low egg production after mild winters (Honkoop et al. 1998) appears to play only a minor role (Beukema et al. 1998). Instead, survival during the first few months of life appears to be the decisive factor for recruitment success. Besides a good match with high food concentrations during the larval stage (Philippart et al. 2003), variability in predation on postlarvae is a probable candidate to explain a significant part of the year-to-year variability in recruitment. On tidal flats, epibenthic predation pressure in the spring and early summer is related to the preceding winter's temperatures: after cold winters (as compared with mild winters), both seasonal arrival on tidal flats of epibenthic predators such as shrimps Crangon crangon and shore crabs Carcinus maenas takes place later in the spring (contributing to a temporal mismatch between these predators and their postlarval bivalve prey: Philippart et al. 2003) as well as in lower numbers, mitigating predation pressure (Beukema 1991, 1992a, Strasser \& Günther 2001).

Van der Veer et al. (1998) and Hiddink et al. (2002) showed that both shrimps and shore crabs eat bivalve spat on Wadden Sea tidal flats. These predators can occur in high abundance on tidal flats; particularly shrimp density can be very high (50 to $100 \mathrm{~m}^{-2}$, cf. Beukema 1992a) and make them a probable candidate for regulation of bivalve spat densities. Results of short-term field experiments on tidal flats in the Wadden Sea and similar areas with exclusion or inclusion cages provide direct evidence that enhanced/reduced predation pressure by shrimps and/or shore crabs reduces/enhances (respectively) the numbers of bivalve spat (Holland et al. 1980, Reise 1985, Mattila et al. 1990, Richards et al. 1999, Hiddink et al. 2002, Strasser 2002, Hunt \& Mullineaux 2002, Flach 2003).

Predation pressure varies not only from year to year, but it also differs from place to place and consistently so between high and low intertidal levels. Due to their short immersion times, the higher intertidal levels are hardly used as feeding areas by aquatic predators, as observed by Sanchez-Salazar et al. (1987) for shore crabs and Beukema (1993) for shrimps. Bivalve spat survival in these near-shore refuges may then be little related to predator abundance and the year-to-year variation may reach its full expression only on lower (i.e. offshore) tidal flats. Thus, predation pressure on early life stages of bivalves may govern temporal as well as spatial patterns in recruitment success of bivalves.

Along with the more or less abrupt climate change that started in 1988, another major change took place in the Dutch Wadden Sea only a few years later. In 1990, all mussel beds (Mytilus edulis) and most of the cockle beds disappeared from the tidal flats because of the combination of intensive fishery and failing recruitment in the preceding years (Dankers \& Zuidema 1995, Beukema \& Cadée 1996, Dankers et al. 2003). This disappearance changed the sediment composition extensively around these former beds, as these species produce large amounts of biodeposits (faeces and pseudo-faeces), enriching the sediment with mud and organic matter (Kröncke 1996). The influence of sediment composition 
on bivalve recruitment success in the Wadden Sea is not well understood. Generally, relationships of such environmental conditions as mud content with animal abundance take a bell-shaped (Gaussian) form. This appears to hold true also for bivalves. Ysebaert et al. (2002) show such curves for Macoma balthica and Cerastoderma edule in the Schelde estuary. A bell-shaped relationship means that moderate changes in sediment composition near the optimal value would hardly affect bivalve abundance, but the effects of similar changes would be substantial at extreme values, i.e. either in very muddy areas or in areas with very low mud content (such as exposed offshore tidal flats). The clean-sandy offshore areas of the western part of the Dutch Wadden Sea (including the most offshore part of Balgzand) became even poorer in fine material between the 1950s and 1990s (see Fig. 5.9 of Zwarts 2003 and Fig. 31a of Ens et al. 2004). This shift may have caused conditions for bivalve recruitment to deteriorate specifically in offshore areas, thus offering another explanation for recruitment declines. Therefore, besides changes in predator abundance, changes in sediment composition should be studied as a possible process underlying long-term changes in bivalve recruitment success. Piersma et al. (2001) show that cockle dredging changes the sediment composition in fished areas (increasing median grain size and decreasing mud content) and these coarser sediments proved to be less suitable for bivalve ( $C$. edule and $M$. balthica) recruitment for long periods ( $>5 \mathrm{yr}$ ). Therefore, possible effects of bottom-disturbing fisheries should be included in a study of declining bivalve recruitment.

In the present study, we use an extensive longterm $(\sim 30 \mathrm{yr})$ data set obtained by consistent macrozoobenthos monitoring on Balgzand, a $50 \mathrm{~km}^{2}$ tidal-flat area in the westernmost part of the Dutch Wadden Sea to describe (1) year-toyear variability in recruitment success in 3 bivalve species: the cockle Cerastoderma edule, the gaper clam Mya arenaria, and the Baltic tellin Macoma balthica, (2) trends in the spatial pattern of their annual recruitment, and (3) year-to-year variation in abundance of 2 epibenthic predators: the shrimp Crangon crangon and the shore crab Carcinus maenas. Another important bivalve, the mussel Mytilus edulis, was not included in the present study because density estimates in this species were far from precise, due to their clustered distribution. The main questions dealt with are thus: Did long-term trends occur in the total recruit densities of the 3 studied bivalve species? Were these trends limited to special parts of the area (high near-shore or low offshore tidal flats)? Was there any temporal or spatial relationship between recruitment success and (1) epibenthic predator abundance (at the time early benthic life stages of bivalves were present) and/or (2) bottom-disturbing fishery?

\section{METHODS}

Since the early 1970 s, the macrozoobenthos community has been monitored at 15 sampling sites (12 transects of $1 \mathrm{~km}$ each and 3 squares of $30 \times 30 \mathrm{~m}$, for locations see Fig. 1a) at a $50 \mathrm{~km}^{2}$ tidal-flat area called 'Balgzand', in the westernmost part of the Dutch Wadden Sea (at about $53^{\circ} \mathrm{N}$ and $5^{\circ} \mathrm{E}$ ). The monitoring

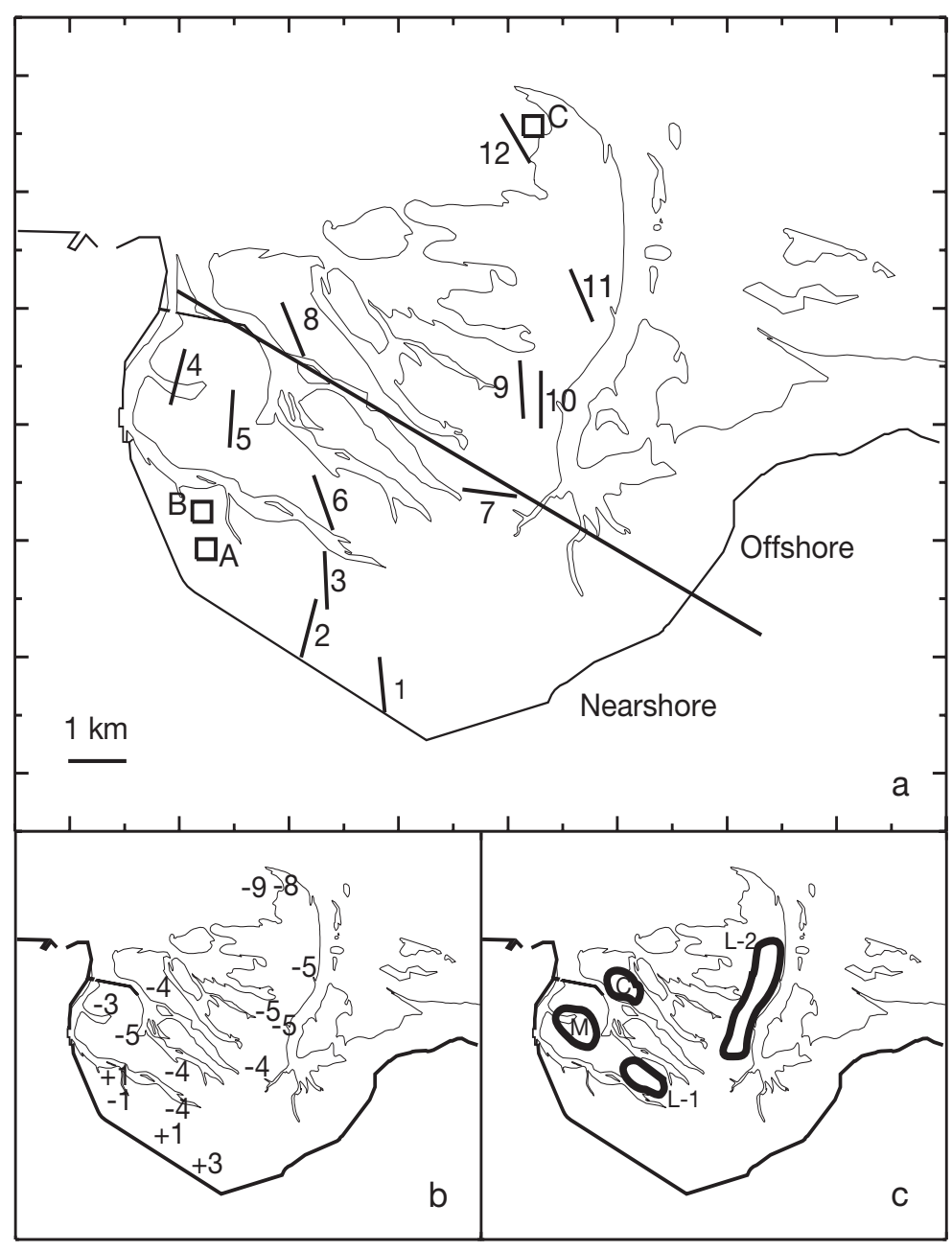

Fig. 1. (a) Map of the Balgzand area showing the location of the 15 sampling sites of the long-term macrozoobenthos monitoring program (straight lines: 12 transects of $1 \mathrm{~km}$ each, numbered 1 to 12 , and 3 small squares of $900 \mathrm{~m}^{2}$ each, indicated by A, B and C). Continuous thin lines surround intertidal areas. The straight heavy line parallel to the SW coast separates the off-shore from the near-shore half of Balgzand. (b) Mean intertidal level of each sampling site expressed in dm difference to MTL. (c) Areas fished temporarily for C (cockles), M (mussels), or L (lug worms; L-1 and L-2 indicate successive periods of lug worm dredging) 
program comprises twice-annual (late winter, usually March, and late summer, usually August) estimates of numbers and biomass of all macrobenthic (those retained on $1 \mathrm{~mm}$ sieves) animal species. Details on sampling sites and methods can be found in earlier publications (e.g. Beukema 1993).

Annual numbers of 0-group bivalves (recruits, spat) have been assessed in late summer in a consistent way since 1973. The $1 \mathrm{~mm}$ sieves used retained spat of a shell length of more than about $1.5 \mathrm{~mm}$. Maximal sizes of spat are usually $\sim 0.5 \mathrm{~cm}$ in Macoma balthica and $\sim 2 \mathrm{~cm}$ in the other 2 species. Along each of the transects, 50 cores were taken at equal intervals $(20 \mathrm{~m})$, covering a total of $0.45 \mathrm{~m}^{2}$ per transect (the 18 to 32 samples taken per square covered 1 to $1.6 \mathrm{~m}^{2}$ ). In the present paper, we use the homogeneous $30 \mathrm{yr}$ summer series 1973 to 2002, inclusive. All data on spat abundance are expressed in $\mathrm{n} \mathrm{m}^{-2}$.

The sampling sites cover the entire intertidal depth range (cf. Fig. 3 of Beukema 1993), which runs on average from about +60 to $-80 \mathrm{~cm}$, compared with meantide level (MTL). Mean levels of each of the 15 sampling sites are given in Fig. 1b in dm from MTL. The level of near-shore sites is generally above MTL and these sites are immersed for less than half of the time. Levels of more offshore sites are increasingly lower and the 2 farthest sites remain immersed during more than half of the low tides. The sampling sites cover a wide range of sediment composition. Mud (material $<60 \mu \mathrm{m}$ ) content of the top $5 \mathrm{~cm}$ of the sediment ranges from $>10 \%$ near the SW coast to $<1 \%$ in the far offshore parts of Balgzand (cf. Fig. 2b of Beukema 1988). Note that the above environmental conditions covary: increasing distances from the SW coast go with declining mud contents of the sediment and lower intertidal levels.

To study distribution patterns in relation to the distance from the coast, we divided the Balgzand area into 8 zones of roughly equal surface area (of $\sim 6 \mathrm{~km}^{2}$ of intertidal area each) and arranged parallel to the SW coast. This division was applied because the 15 sampling sites were distributed over Balgzand in a more or less random fashion and, consequently, not all geographic zones were equally well represented. The number of sampling sites per zone varied from 1 to 3 (cf. Table 1). The SW coast was chosen as the starting point because on Balgzand the major gradients (depth and sediment composition) run perpendicular to this coast (cf. Fig. 1b and Beukema 1988, Fig. 2). Mean recruit densities for each zone were calculated by averaging data obtained from the 1 to 3 sampling sites located within the zone. The estimated densities for each zone were used to estimate for each year (1) the proportions of all spat that had recruited in the offshore part of Balgzand (i.e. $>4 \mathrm{~km}$ from the $\mathrm{SW}$ coast, covering slightly less than half of the total intertidal Balgzand area) and (2) the centres of distribution (as a mean distance in $\mathrm{km}$ from the SW coast).

Measures for the annual abundance of shrimps and shore crabs were obtained from various sources. The late-winter (March) monitoring program at low tide at 15 sites on Balgzand provided data on mean numbers and biomass of mostly juvenile shrimps and shore crabs for each of the $30 \mathrm{yr}$ from 1973 to 2002, and that of late summer (August) for each of the $23 \mathrm{yr}$ from 1980 to 2002. A fish trap (fyke net with meshes of $5 \times 5 \mathrm{~mm}$ ), placed at the southern point of Texel in the main tidal inlet of the western Wadden Sea and emptied almost daily, provided almost year-round data on the number of adult shrimps and shore crabs since 1960 (Van der Veer et al. 1992, Spaargaren 2000). We used mean annual data of catches in the spring and autumn seasons of period from 1973 to 2002. The abundance of small shrimps on the tidal flats was further monitored in detail (but only since 1983) at 3 coastal (0.5 to $1.5 \mathrm{~km}$ from the SW coast) sites on Balgzand (cf. Fig. 1a, near squares $\mathrm{A}$ and $\mathrm{B}$ ) by taking samples at low tide 1 to 3 times per month during the periods from late April to

Table 1. Cerastoderma edule. Long-term (1973 to 2002, incl.) changes in annual (August) estimates of numerical densities of 0-group cockles in various zones of the Balgzand area (characterized by their distance in km from the SW coast, see Fig. 1), expressed as: (1) correlation $r$ with year number, (2) slope of plot against year number (i.e. mean change of number of recruits per year) and (3) mean numbers ( $\mathrm{n} \mathrm{m}^{-2}$ ) found in the first (1973 to 1987) and in the second (1988 to 2002) half of the period of observation, with their quotient (ratio $2 \mathrm{nd} / 1$ st period). Statistical significance indicated by ${ }^{*} \mathrm{p}<0.05,{ }^{* *} \mathrm{p}<0.01$, or ${ }^{* * *} \mathrm{p}<0.001$ (Spearman rank correlation test with $\mathrm{n}=30$ for difference with 0.0 of correlations with year number and Mann-Whitney test with $\mathrm{n}=15$ and 15 for difference with 1.0 of ratio values)

\begin{tabular}{|lcccrrr|}
\hline $\begin{array}{l}\text { Balgzand } \\
\text { zone } \\
(\mathrm{km})\end{array}$ & $\begin{array}{c}\text { No. } \\
\text { of sites } \\
(\mathrm{n})\end{array}$ & $\begin{array}{c}\text { Correlation } \\
\text { with yr } \\
\text { number }(\mathrm{r})\end{array}$ & $\begin{array}{c}\text { Slope of } \\
\text { linear fit } \\
\left(\mathrm{n} \mathrm{m}^{-2} \mathrm{a}^{-1}\right)\end{array}$ & $\begin{array}{r}\text { 15-yr mean recruit numbers } \\
\left(\mathrm{n} \mathrm{m}^{-2}\right)\end{array}$ & $\begin{array}{c}\text { 2nd } \\
\left(\mathrm{n} \mathrm{m}^{-2}\right)\end{array}$ & $\begin{array}{c}\text { Ratio } \\
(2 \mathrm{nd} / 1 \mathrm{st})\end{array}$ \\
\hline $0-10$ & 15 & $-0.41^{*}$ & -6 & 174 & 62 & $0.36^{* *}$ \\
$0-4$ & 9 & -0.14 & -2 & 109 & 70 & 0.64 \\
$4-10$ & 6 & $-0.56^{* *}$ & -13 & 278 & 34 & $0.12^{* * *}$ \\
$0-1$ & $3(1,2, \mathrm{~A})$ & $+0.44^{*}$ & +2 & 15 & 57 & $3.79^{*}$ \\
$1-2$ & $2(3, \mathrm{~B})$ & -0.25 & -5 & 208 & 128 & 0.61 \\
$2-3$ & $2(5,6)$ & -0.23 & -1 & 194 & 110 & $0.57^{*}$ \\
$3-4$ & $2(4,7)$ & -0.18 & -1 & 45 & 39 & 0.86 \\
$4-5$ & $1(8)$ & $-0.41^{*}$ & -18 & 383 & 42 & $0.11^{* *}$ \\
$5-6$ & $2(9,10)$ & $-0.50^{* *}$ & -16 & 290 & 25 & $0.09^{* *}$ \\
$6-8$ & $1(11)$ & $-0.50^{* *}$ & -16 & 395 & 114 & $0.29^{* *}$ \\
$8-10$ & $2(12, \mathrm{C})$ & $-0.61^{* * *}$ & -5 & 156 & 0 & $0.00^{* * *}$ \\
\hline
\end{tabular}



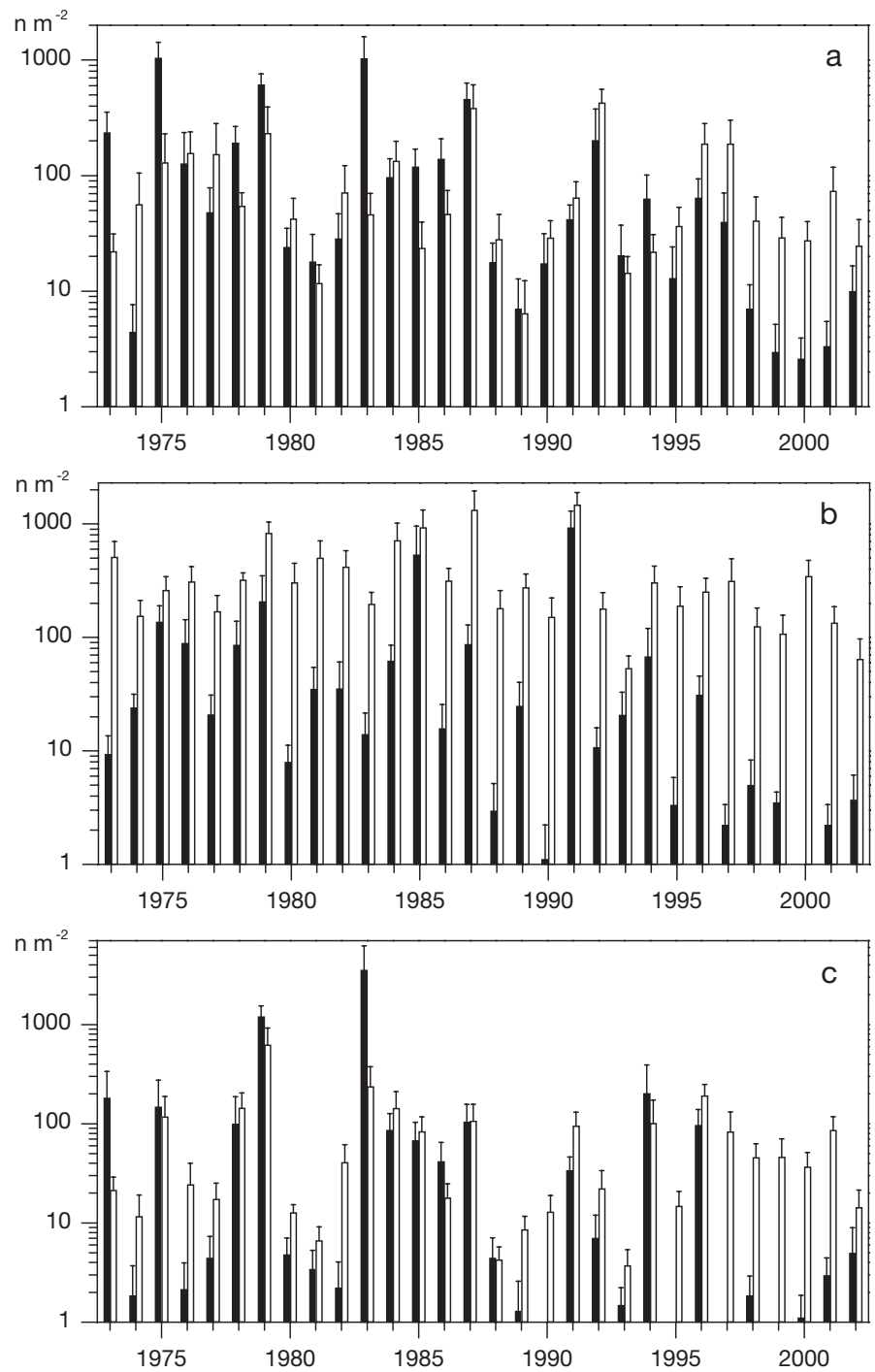

Fig. 2. Time course (1973 to 2002) of annual means of recruitment $\left(\mathrm{n} \mathrm{m}^{-2}\right)$ of 3 species in 2 parts of Balgzand: (black columns) off-shore (sites 8, 9, 10, 11, 12, and C, see Fig. 1a) and (white columns) near-shore (remaining 9 sites). Error bars indicate $1 \mathrm{SE}$ with $\mathrm{n}=6$ and 9, respectively. (a) Cerastoderma edule, (b) Macoma balthica, (c) Mya arenaria

July or August (cf. Beukema 1992a for locations of sampling sites and methods).

Bottom-disturbing fishery activities were recorded from direct visual observations and from their consequences, i.e. bottom traces that can remain visible for months (cf. Plate I of Beukema 1995), and confirmed by substantially enhanced mortality rates of adult cockles or mussels at our nearby sampling sites. The recorded fishery areas are shown in Fig. 1c. Possible effects on recruitment were studied by comparing recruit densities in August in the fished area with densities in the remaining part of Balgzand. For each year of the 1973 to 2002 period, and for each of the fishery areas shown in Fig. 1c, we calculated a relative recruitment ratio, i.e. the density in the fished area divided by the mean density in the non-fished part of Balgzand; we averaged these local ratio values for groups of $\sim 5$ successive years and allotted these $5 \mathrm{yr}$ averages to 1 of 3 periods: before, during, and after fishing (sometimes data for a 'before' or 'after' period were lacking, depending on the start and end of the fishing period relative to the start and end of the period of observation).

Non-parametric statistical methods were applied, including the Spearman rank correlation test (to evaluate time trends) and the Mann-Whitney test (to evaluate differences in the level between groups of data), because they make no specific demands on the character of the data.

\section{RESULTS}

\section{Long-term trends in recruit numbers}

\section{The cockle Cerastoderma edule}

During the 1973 to 2002 period, the 15 station (totalBalgzand) means of cockle recruit densities declined significantly from an average of a few hundred in the 1970 s to tens $\mathrm{m}^{-2}$ around 2000. In the second half of the period of observation, the annual mean of the total number of cockle recruits on Balgzand was only about one-third of this mean found in the first half of the period (top line of Table 1).

Not all parts of Balgzand showed the same trends (Fig. 2a). Significantly declining trends were observed particularly at the sampling stations located in the offshore half of the Balgzand area (data shown in the 4 lower lines of Table 1): significantly negative values of long-term trends (rank correlation with year number) as well as low (significantly <1.0) ratio values (2nd/1st half of period) occurred at distances of $>4 \mathrm{~km}$ from the SW coast. In most of this offshore part of Balgzand, the average rates of decline of cockle recruit numbers amounted to $\sim 17 \mathrm{~m}^{-2} \mathrm{yr}^{-1}$, i.e. recruit numbers declined from several hundred to some tens $\mathrm{m}^{-2}$ over the period of observation. At most of these offshore sites, recruitment was an order of magnitude lower in the second half than in the first half of the period of observation (see black columns in Fig. 2a).

At distances between 1 and $4 \mathrm{~km}$ from the SW coast (5th to 7 th line of Table 1), mean recruit numbers were also rather high, but there were hardly any consistent longterm trends at the sampling sites within this zone. On the other hand, the (relatively minor) recruitment at the 3 sampling sites closest to the shore (at 0 to $1 \mathrm{~km}$ ) showed statistically significant increases rather than declines during the period of observation (4th line of Table 1). 
As a result of the above trends, the proportion of all Balgzand cockle recruits that had settled each year in the offshore half of the area (i.e. at $>4 \mathrm{~km}$ from the SW coast) declined significantly from about $70 \%$ in the 1970 s to about $20 \%$ around 2000 (Fig. 3a). Averages for the 2 halves of the total observation period amounted to 62 and $36 \%$, respectively, (the ratio 0.59 differed significantly, $\mathrm{p}<0.01$, from 1.0, cf. Table 2).

The annual value of the calculated mean distance of recruits from the SW coast (i.e. the location of the centre of distribution) varied from $>7$ to $<2 \mathrm{~km}$, and declined significantly in the course of the period of
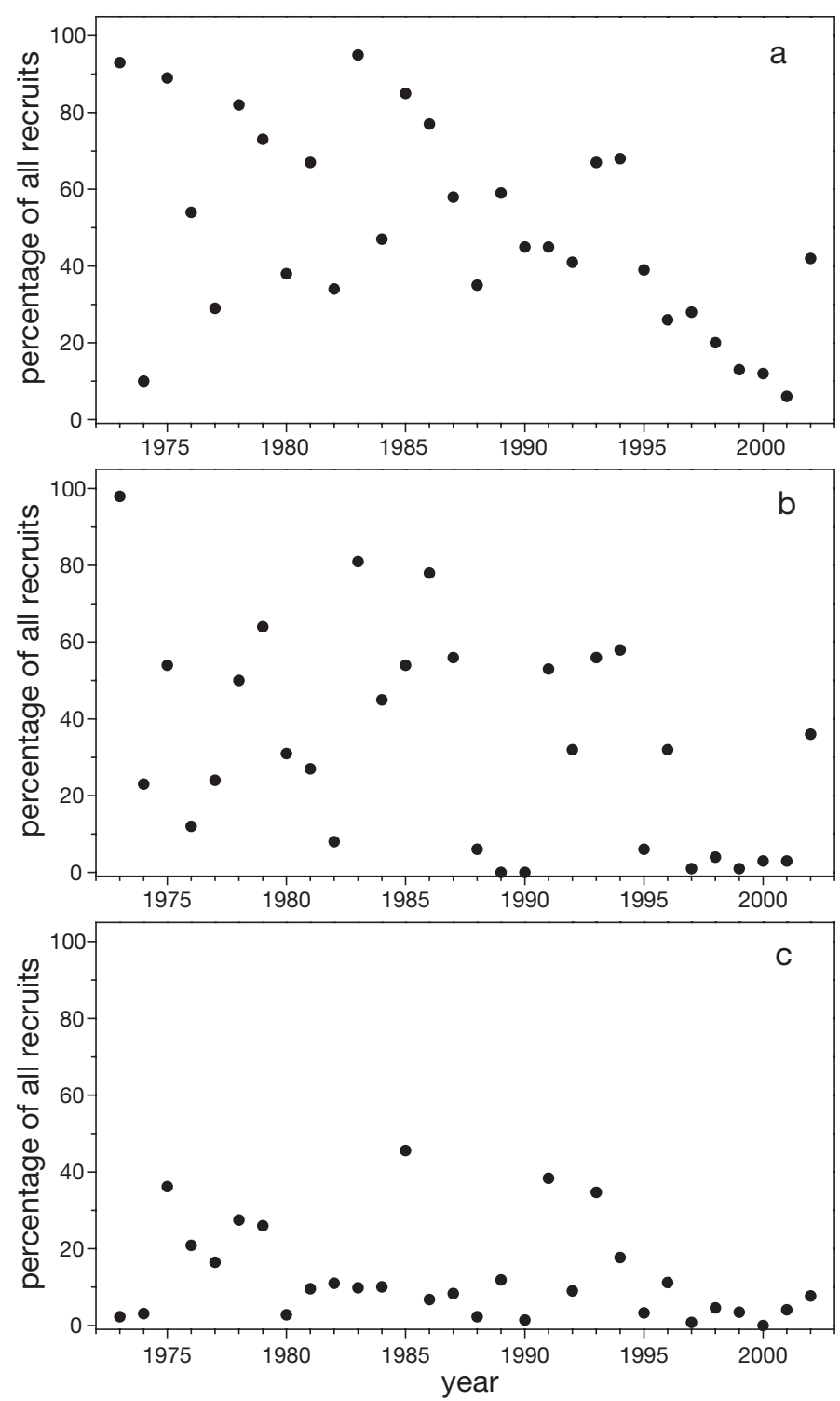

Fig. 3. Proportions (\%) of all Balgzand recruits of 3 species that were found in the off-shore part of the area, i.e. at $>4 \mathrm{~km}$ from the SW coast in each of 30 successive summers (1973 to 2002) in: (a) Cerastoderma edule: correlation with year number: $\mathrm{r}=-0.52$, $\mathrm{n}=30, \mathrm{p}<0.01$; (b) Mya arenaria: $\mathrm{r}=-0.43, \mathrm{p}<0.02$; (c) Macoma balthica: $\mathrm{r}=-0.28, \mathrm{p}=0.1$ observation $(\mathrm{r}=-0.52, \mathrm{n}=30, \mathrm{p}<0.01)$. For the 2 halves of the observation period, mean values amounted to significantly differing distances of 4.5 and $3.2 \mathrm{~km}$ (Table 2). Thus, nowadays the centre of distribution of cockle recruits is, on average, closer to the shore, and therefore at higher intertidal levels than in the early years of observation. The decline of the importance of offshore areas for cockle recruitment was the main cause of this shoreward shift, but also the increasing numbers found close to the coast contributed to this shift.

The 2 simultaneous trends observed above (declining recruitment success and shoreward shift of centres of distribution) must give rise to a relationship between total annual recruit numbers and location of their centres of distribution. This correlation proved to be significant (Fig. 4a). Thus, strong year classes of cockles were characterised by a relatively off-shore location of their centres of distribution, i.e. by a highly successful recruitment, especially in offshore intertidal areas.

\section{Comparisons with other bivalve species}

In the 2 other species studied, Mya arenaria and Macoma balthica, the trends observed were similar to those described above for Cerastoderma edule. The decline of recruitment success in the course of the $30 \mathrm{yr}$ period was observed in these species, too, statistically significant both in the entire Balgzand area and in the offshore part of Balgzand (Table 2). However, a significant increase of recruitment success in the near-shore area was not observed in $M$. arenaria or $M$. balthica. The proportions of total recruitment found in the offshore half of Balgzand declined in the course of the observation period in all 3 species (Fig. 3, Table 2), although not significantly so in $M$. balthica. The shoreward shifts in the centres of spat distribution were significant in all species (Table 2) as well as the positive relationships between recruitment success and distance of distribution centre from the coast (Fig. 4).

\section{Abundance of epibenthic predators \\ Long-term trends}

The long-term data of the monitoring series on Balgzand tidal flats in late winter and early spring indicated significant increases in mean biomass values as well as numerical densities of the shrimp Crangon crangon (Table 3). In March, the mean abundance of shrimps at the 15 sites more than doubled from the first to the 
Table 2. Between-species (Cerastoderma edule, Mya arenaria and Macoma balthica) comparisons of some characteristics of long-term trends in annual recruitment observed on Balgzand, viz. mean 0-group densities (in $\mathrm{n} \mathrm{m}^{-2}$ ) observed in August in (1) total area (15 sites), (2) off-shore part of the area ( $>4 \mathrm{~km}$ from SW coast, 6 sites) and (3) near-shore area $(<1 \mathrm{~km}$ from coast, 3 sites). The 2 bottom lines show derivatives of these data, viz. proportion (\%) of all 0-group found in the off-shore part of Balgzand and estimated center of distribution of 0 -group members (in $\mathrm{km}$ from SW coast). The numbers given represent the 15 yr mean values $\left(\mathrm{n} \mathrm{m}^{-2}\right)$ for the second (1988 to 2002) and the first (1973 to 1987) period and their quotient (2nd/1st). Thus, ratio values $<1$ indicate declines. Statistical significance indicated by: ${ }^{*} \mathrm{p}<0.05$ or ${ }^{* *} \mathrm{p}<0.01$ (MannWhitney test with $\mathrm{n}=15$ and 15 )

\begin{tabular}{|c|c|c|c|}
\hline & $\begin{array}{c}\text { C. edule } \\
\text { 2nd/1st = ratio }\end{array}$ & $\begin{array}{l}\text { M. arenaria } \\
\text { 2nd/1st = ratio }\end{array}$ & $\begin{array}{c}\text { M. balthica } \\
\text { 2nd/1st = ratio }\end{array}$ \\
\hline $\begin{array}{l}\text { Balgzand } \\
\text { recruitment ( } \mathrm{n} \mathrm{m}^{-2} \text { ) }\end{array}$ & $62 / 174=0.36^{* *}$ & $40 / 137=0.29^{* *}$ & $197 / 321=0.61^{* *}$ \\
\hline $\begin{array}{l}\text { Off-shore } \\
\text { recruitment }\left(\mathrm{n} \mathrm{m}^{-2}\right)\end{array}$ & $34 / 278=0.12^{* * *}$ & $28 / 227=0.13^{*}$ & $76 / 120=0.63^{* *}$ \\
\hline $\begin{array}{l}\text { Near-shore } \\
\text { recruitment }\left(\mathrm{n} \mathrm{m}^{-2}\right)\end{array}$ & $57 / 15=3.79^{*}$ & $48 / 44=1.09$ & $449 / 507=0.89$ \\
\hline $\begin{array}{l}\text { Proportion } \\
\text { off-shore (\%) }\end{array}$ & $36 / 62=0.59^{* *}$ & $20 / 47=0.43^{* *}$ & $10 / 16=0.62$ \\
\hline Distance center $(\mathrm{km})$ & $3.2 / 4.5=0.71^{*}$ & $2.4 / 3.9=0.62^{* *}$ & $1.6 / 2.0=0.79^{*}$ \\
\hline
\end{tabular}

high coastal to low offshore zones on Balgzand.

\section{Shrimp predation and bivalve recruitment success}

\section{Assessment of relevant season}

Because shrimps on tidal flats are relatively small (cf. Fig. 6 of Beukema 1992a: on most sampling occasions mean lengths were between 1 and $2 \mathrm{~cm}$ ), bivalve recruits are suitable prey only as long as they are small, i.e. particularly during the first weeks after their settlement. In most marine invertebrates, the onset of benthic postlarval life is a period with high mortality rates and variation in intensity of mortality factors during this period may determine final cohort size (Gosselin and Qian 1997). Examples of postlarval settling success determining

second half of the 1973 to 2002 period. The detailed monitoring data (at 3 sites on Balgzand) revealed similarly increasing trends during the 1983 to 2002 period in April and in May, but not in June and July (Table 3). The data on daily fyke catches in the main tidal inlet of the western Wadden Sea in the 1973 to 2002 period revealed even larger increases in (large) shrimps than observed on the tidal flats (Table 3 ).

In the other important epibenthic predator, the shore crab Carcinus maenas, no significant changes were found in similar data sets (Table 3).

\section{Spatial trends}

Both in the late-winter and in the late-summer samples taken annually at 15 sampling sites on Balgzand (see Fig. 1a), shrimp biomass values declined significantly ( $p<0.0001)$ with increasing intertidal level (Fig. 5a,b, respectively) and with decreasing distance from the coast $(p<0.0001$; Fig. 5c,d). At the high (above or close to MTL) sampling sites near the shore (within $1 \mathrm{~km}$ of the SW coast of Balgzand, sites 1, 2, A, and $B$, see Fig. 1), mean shrimp biomass values were less than one-tenth of the mean values observed at the sites farthest away from the coast. Shrimps in samples taken at the high coastal sites were on average smaller (mean lengths usually between 1 and $1.5 \mathrm{~cm}$ ) than at the low offshore sites (mean lengths usually around $2 \mathrm{~cm}$ ). This size difference largely explained the observed increase of biomass from final cohort size in Macoma balthica have been published by Bachelet (1986) and Beukema et al. (1998). M. balthica settlement usually begins in April (at a length of $\sim 0.2 \mathrm{~mm}$ ) and peak numbers of sievecaught postlarvae (of a length of between 0.5 and $1 \mathrm{~mm}$ ) are usually observed in the second half of May or in early June (Günther 1991, Beukema et al. 1998, Van der Veer et al. 1998). In the other 2 species, maximal settlement appears to occur slightly later in the season. In 1993, maximal numbers of postlarvae of 0.5 to $1.0 \mathrm{~mm}$ shell length of all 3 species were present on Balgzand in the first half of June (Van der Veer et al. 1998). This points to the presence of numerous just-settled $M$. balthica, Cerastoderma edule and Mya arenaria postlarvae (with a size of 0.2 to $0.3 \mathrm{~mm}$ ) in the second half of May. Unpublished observations (by R. Dekker) indicate similar early settlement in the course of May in $M$. arenaria in nearly all of the $10 \mathrm{yr}$ of his observations, but in $C$. edule settlement was 1 or 2 wk later in about half of these years. Günther (1992) observed maximal numbers of $M$. arenaria postlarvae in the German Wadden Sea in late May and early June. The relevant season to study possible relationships between shrimp abundance and bivalve recruitment success on tidal flats of the Wadden Sea will thus be the May to June period, with an emphasis on May for $M$. balthica and $M$. arenaria and mid-May to midJune for $C$. edule. In early summer, most bivalve spat, particularly $C$. edule and $M$. arenaria, will rapidly outgrow predation by small shrimps. 

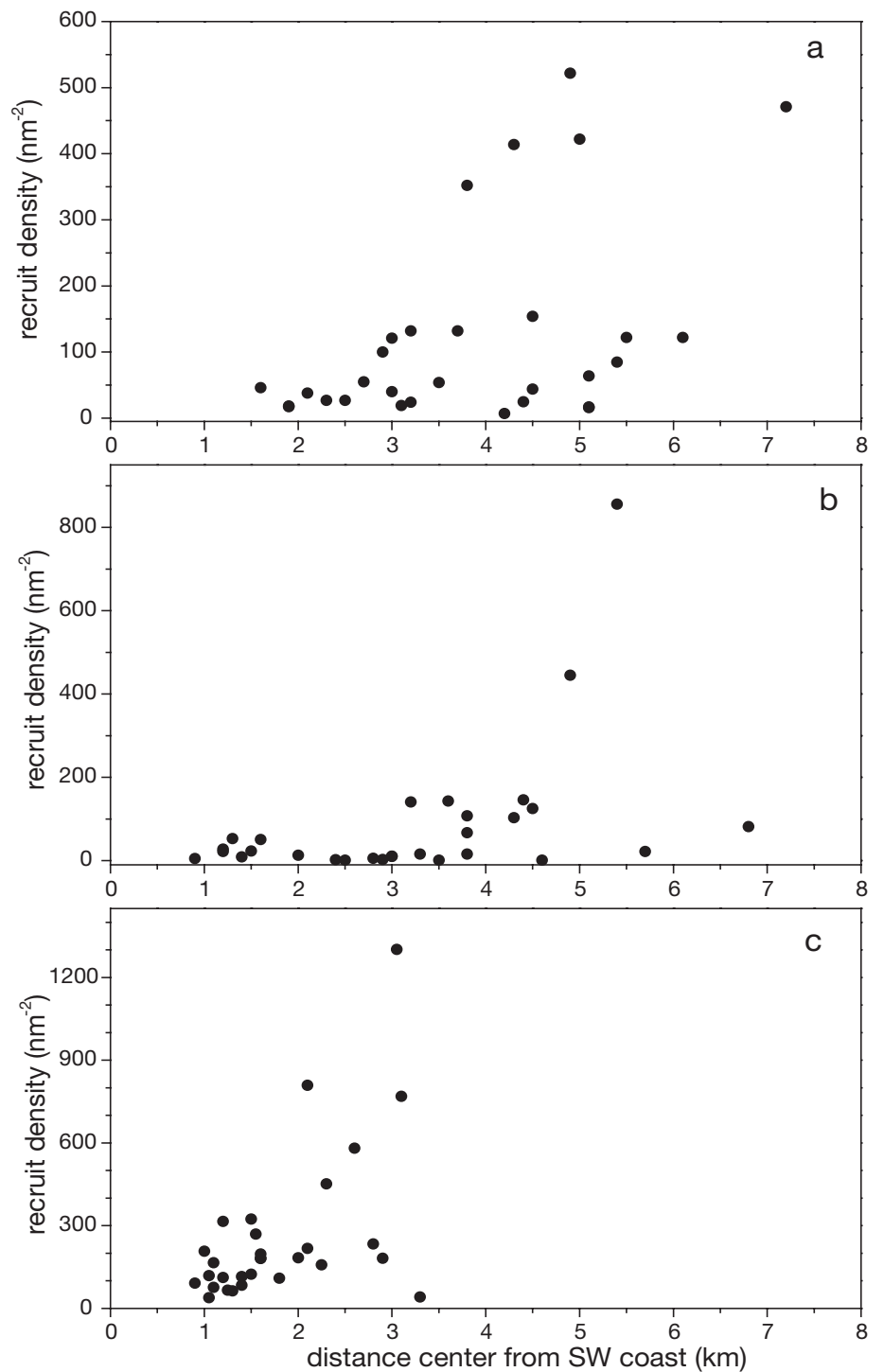

Fig. 4. Relationships between distance of center of recruitment (in km from SW coast of Balgzand) and recruitment success (in mean number of spat $\mathrm{m}^{-2}$ of all 15 sampling sites). One point for each of the $30 \mathrm{yr}$ of the 1973 to 2002 period for: (a) Cerastoderma edule: $\mathrm{r}=+0.48, \mathrm{n}=30, \mathrm{p}<0.01$; (b) Mya arenaria: $\mathrm{r}=$ $+0.44, \mathrm{p}<0.02 ;$ (c) Macoma balthica: $\mathrm{r}=+0.54, \mathrm{p}<0.01$

Shrimp abundance and subsequent bivalve recruitment

The detailed 20 yr data series on shrimp biomass refers to a restricted part of Balgzand, located $<1.5 \mathrm{~km}$ from the SW coast (near the sampling sites A and B in Fig. 1a). This is well within the main recruitment zone of $M$. balthica (cf. Fig. 4c), but the coastal zone is beyond the usual centres of recruit distribution in the other 2 species (Fig. 4a,b). Shrimp biomass values are higher by a factor of 2 to 3 in the latter areas (cf. Fig. 5), and this is also true in May and June (unpubl. obs. by R. Dekker in a small number of years). Moreover, the
Table 3. Long-term trends in epibenthic predator (shrimp Crangon crangon and shore crab Carcinus maenas) abundance (B= biomass in $\mathrm{g}$ AFDW $\mathrm{m}^{-2}$ and $\mathrm{N}=$ number $\mathrm{m}^{-2}$ ) in the westernmost part of the Wadden Sea, as observed in benthos samples taken on the tidal flats of Balgzand and in fyke catches in the adjacent tidal inlet. Data shown are (1) correlations $r$ with year number (n) for the 1973 to 2002 (in March) or the 1980 to 2002 (in August) period for the 15 sites, or for the 1983 to 2002 period for the 3 sites, and (2) ratio values of mean abundance in 2 nd and 1 st half of these periods. Statistical significance shown by * $\mathrm{p}<0.05$ or ${ }^{* *} \mathrm{p}<0.01$ (Spearman rank correlation test with $\mathrm{n}=20,23$, or 30 for difference of $r$ with 0.0 and Mann-Whitney test with $n=10$ and 10 , or 12 and 11 , or 15 and 15 for difference of ratio with 1.0)

\begin{tabular}{|llll|}
\hline & $\begin{array}{r}\text { Number } \\
\text { of years } \\
\end{array}$ & $\begin{array}{c}\text { Corre- } \\
\text { lation } \\
\text { coefficient, }\end{array}$ & $\begin{array}{c}\text { Ratio } \\
\text { 2nd/1st } \\
\text { period }\end{array}$ \\
\hline Shrimps & & & \\
B, March, tidal flats, 15 sites & 30 & +0.32 & $2.2^{* *}$ \\
B, April, tidal flats, 3 sites & 20 & $+0.55^{*}$ & $2.1^{*}$ \\
B, May, tidal flats, 3 sites & 20 & $+0.55^{*}$ & $1.7^{*}$ \\
B, June, tidal flats, 3 sites & 20 & -0.02 & 1.1 \\
B, July, tidal flats, 3 sites & 20 & -0.12 & 1.0 \\
B, August, tidal flats, 15 sites & 23 & +0.25 & 1.1 \\
N, March, tidal flats, 15 sites & 30 & $+0.44^{*}$ & $2.4^{* * *}$ \\
N, spring, tidal inlet & 30 & $+0.57^{* *}$ & $6.1^{*}$ \\
N, autumn, tidal inlet & 30 & $+0.55^{* *}$ & $4.3^{* *}$ \\
Shore crabs & & & \\
B, March, tidal flats, 15 sites & 30 & +0.25 & 1.7 \\
B, August, tidal flats, 15 sites & 23 & -0.09 & 0.6 \\
N, March, tidal flats, 15 sites & 30 & +0.09 & 1.3 \\
N, spring, tidal inlet & 30 & -0.12 & 0.9 \\
N, autumn, tidal inlet & 30 & -0.01 & 1.0 \\
\hline
\end{tabular}

trends observed in the March data (for all 15 Balgzand sites) were similar to those of April in the restricted area where shrimps were monitored in detail (cf. top lines of Table 3). Therefore, we think that the shrimp biomass values we observed in the restricted area provide a useful index for annual May-to-June shrimp abundance in other Balgzand areas as well.

In all 3 bivalve species, total-Balgzand (15 sites) means of recruit numbers were significantly higher in years with low rather than high shrimp abundance, in May as well as in June (Table 4). In all 3 bivalve species, these negative relationships between shrimp abundance and subsequent recruitment were particularly strong for the shrimp abundance in May, and were also significant for the June shrimp data in 2 species (C. edule and $M$. arenaria). Shrimp biomass values in July and subsequent recruitment appeared to be negatively related, too, but no longer significantly so.

Spatial variation in shrimp abundancebivalve recruitment relationship

In Macoma balthica, all 15 local values of $\mathrm{r}$ for the correlation between May shrimp biomass and August 

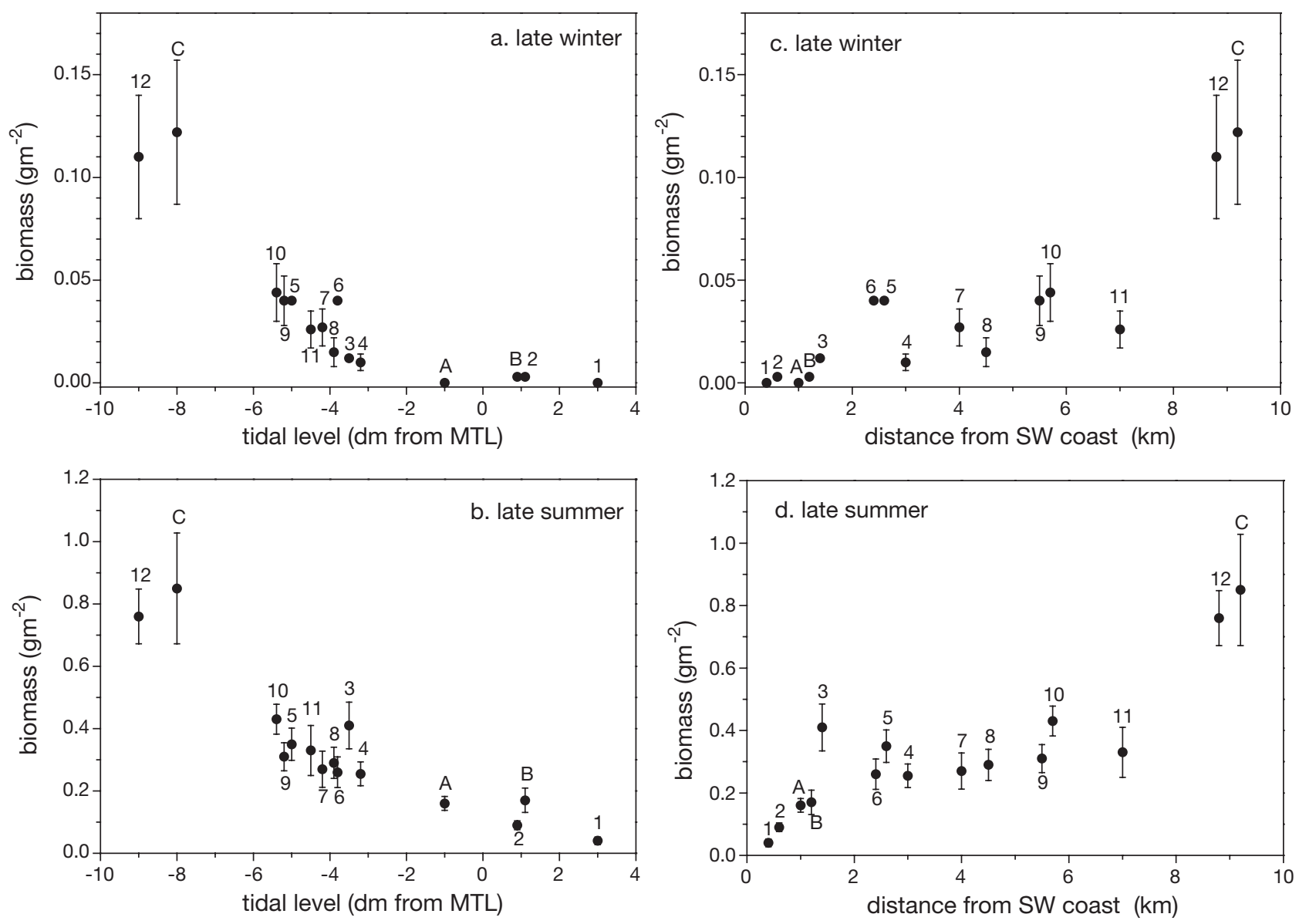

Fig. 5. Crangon crangon. Relationship between mean $( \pm 1 \mathrm{SE})$ shrimp biomass $\left(g\right.$ AFDW m $\left.{ }^{-2}\right)$ and intertidal level (a,b: in dm difference from MTL) or distance from the coast (c,d: in km from the SW coast of Balgzand). Each of the 15 sampling sites of the long-term monitoring program indicated by the number shown in Fig. 1a. (a,c) Means of 30 estimates in late winter (1973 to 2002); correlation with level: $\mathrm{r}=-0.85, \mathrm{n}=15, \mathrm{p}<0.0001$ and correlation with distance: $\mathrm{r}=+0.85, \mathrm{n}=15, \mathrm{p}<0.0001$. (b,d) Means of 23 estimates in late summer (1980 to 2002). Correlation with level: $\mathrm{r}=-0.95, \mathrm{n}=15, \mathrm{p}<0.0001$ and with distance: $\mathrm{r}=+0.90$, $\mathrm{n}=15, \mathrm{p}<0.0001$

recruit density in the $20 \mathrm{yr}$ period from 1983 to 2002 were negative and statistically significantly (Spearman rank correlation test: $\mathrm{p}<0.05,1$-sided) at 12 out of the 15 sampling sites. Sites showing strong relationships

Table 4. Relationships (expressed in Spearman rank correlation coefficients) between monthly (May, June, and July) biomass estimates of shrimps ( $\mathrm{mg} \mathrm{m}^{-2}$, means of 3 coastal Balgzand sites) and subsequent (August) recruit densities of 3 bivalve species (n $\mathrm{m}^{-2}$, means of all 15 Balgzand sites) for the $20 \mathrm{yr}$ period from 1983 to $2002 .{ }^{*},{ }^{* *}$ or ${ }^{* * *}$ indicate statistical significance of difference between $\mathrm{r}$ value and 0 in Spearman rank tests (with $\mathrm{n}=20 ; \mathrm{p}<0.05, \mathrm{p}<0.01$, and $\mathrm{p}<0.001$, respectively)

\begin{tabular}{|llll|}
\hline Species & May & June & July \\
\hline Cerastoderma edule & $-0.75^{* * *}$ & $-0.55^{*}$ & -0.14 \\
Mya arenaria & $-0.65^{* *}$ & $-0.62^{* *}$ & -0.31 \\
Macoma balthica & $-0.73^{* *}$ & -0.36 & -0.25 \\
\hline
\end{tabular}

between shrimp abundance and subsequent recruitment also showed large declines of recruit numbers in the course of the 1983 to 2002 period (Fig. 6a, Spearman $\mathrm{r}=+0.51, \mathrm{n}=14, \mathrm{p}<0.05,1$-sided). Little decline in recruitment occurred particularly at the 2 high-level sites closest to the shore (points marked 1 and 2 in Fig. 6a) where shrimps are sparse in all seasons (Fig. 5). At these sites, the correlation coefficients of M. balthica recruitment versus May shrimp abundance were weak (Fig. 6a).

In Cerastoderma edule, r-values for the relationship between May shrimp biomass and subsequent (August) recruit numbers were significantly negative at 8 sampling sites. As in Macoma balthica, long-term declines of recruit densities (2nd versus 1st half of the observation period) were larger where the relationship between shrimp abundance and subsequent cockle recruit numbers was stronger negative (Fig. 6b, Spear- 

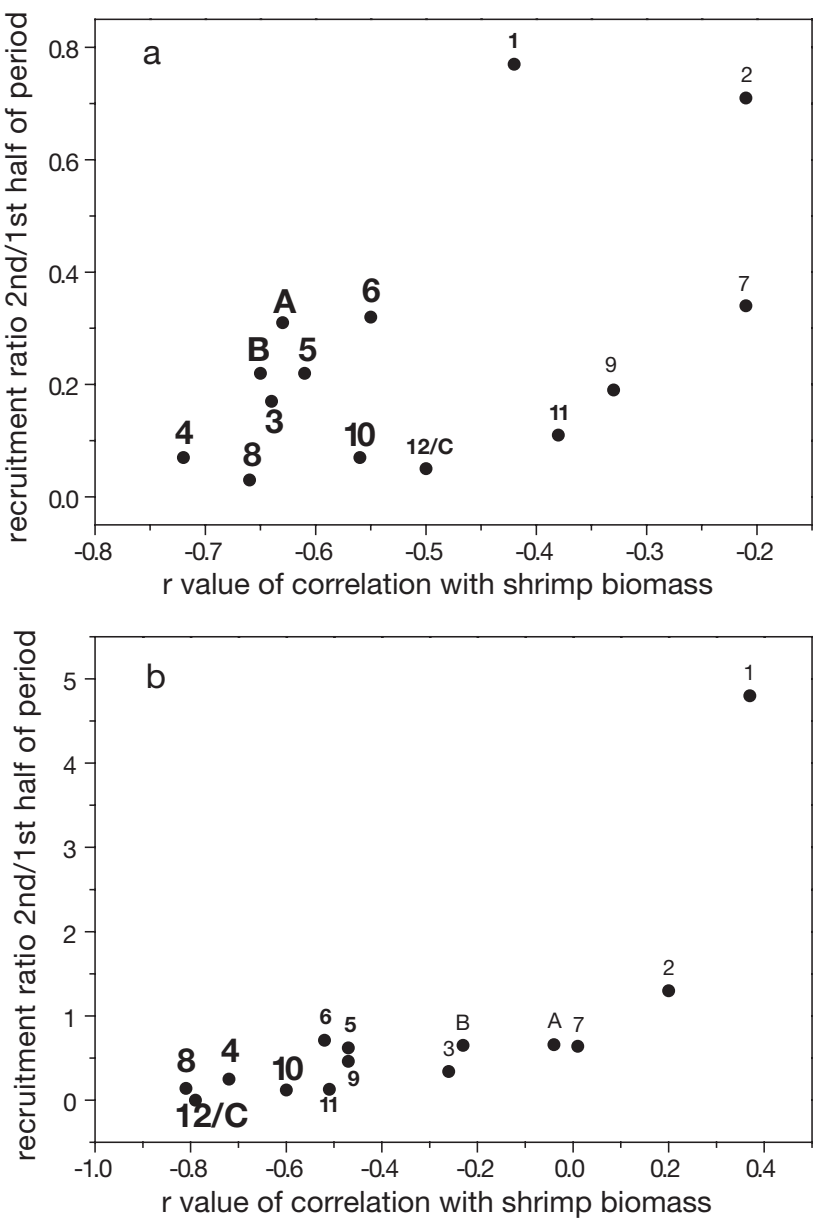

Fig. 6. (a) Macoma balthica; (b) Cerastoderma edule. Relationship between local values for (horizontal axis) the strength of the (Spearman rank) correlation between shrimp biomass in May and subsequent recruit density in August (as in Table 4 for entire Balgzand) and (vertical axis) relative change of recruitment success at that site between the 19831992 and the 1993-2002 period (as a ratio of annual mean of 2nd/1st period). One point for each of 14 sampling sites on Balgzand (data of the 2 neighbouring poor-recruitment sites $\mathrm{C}$ and 12 combined, see Fig. 1a). The points are marked by their numbers shown in Fig. 1a. Statistical significance of Spearman rank correlation between recruitment and shrimp biomass indicated for each point by bold numbers $(p<0.05)$ or additionally by larger type size $(p<0.01)$. See text for statistical significance of relationships between values on horizontal and vertical axis

man $\mathrm{r}=+0.79, \mathrm{n}=14, \mathrm{p}<0.01)$. Again, the 2 sites numbered 1 and 2, located at the shortest distance from the shore and at the highest intertidal level and with the lowest shrimp biomass, showed the smallest declines (in fact, even increases) in recruitment success as well as a total absence of a negative correlation with preceding shrimp abundance. Even when these 2 extreme points are left aside, the correlation of the remaining points is statistically significant $(\mathrm{r}=+0.67, \mathrm{n}=12, \mathrm{p}<$ $0.05)$.

\section{Sediment composition and cockle recruitment}

The Balgzand data series revealed a bell-shaped relationship between the proportion of fine material in the upper sediment layer and the chance of cockle recruitment being successful (Fig. 7). Fig. 7 refers to mud content observations in March, i.e. at the annual minimum (wind force, tidal range and tidal-current velocity show higher values in winter than in summer). In late summer, by the end of long periods of quiet weather, mud contents can be substantially higher; particularly in low-mud areas, where they may be more than twice the winter values.

The criterion for success was arbitrarily set at spat densities in August of either $>10$ or $>100 \mathrm{~m}^{-2}$ (solid and open points, respectively, in Fig. 7). Both threshold values yielded a similarly shaped curve; Fig. 7 shows only one of the lower criterion as a best fitting polynomial curve (this curve is highly similar to a fitted Gaussian curve). Note that in both cases the maximal frequency of recruitment success was observed at sampling stations with mud contents of about 0.5 to $3 \%$ in late winter (corresponding to about 1 to $10 \%$ in summer). Both at higher and lower mud contents, the frequency of successful cockle recruitment tended to be lower. Especially at low mud values $(<0.5 \%)$, a small change (of some tenth of a percent) in mud content appears to mean a lot for recruitment, whereas the effect on recruitment of such minor change in sediment composition would remain immeasurable at above-optimum mud contents.

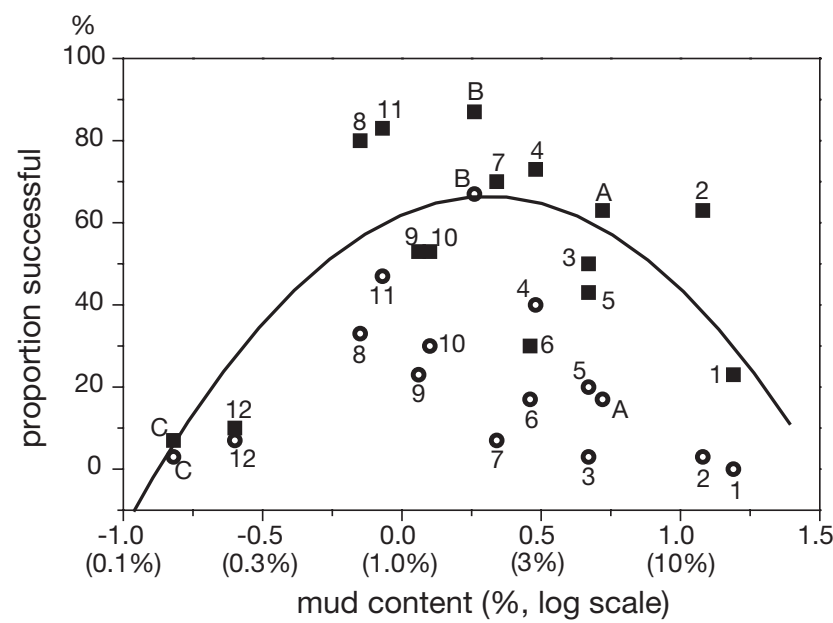

Fig. 7. Cerastoderma edule. Relationship between content of mud (material $<60 \mu \mathrm{m}$ ) in the upper $5 \mathrm{~cm}$ of sediment $\left({ }^{10} \mathrm{log}\right.$ scale, non-transformed values added between brackets) and probability of a recruitment of $(\mathbf{\square})>10 \mathrm{~m}^{-2}$ or $(\mathbf{0})>100 \mathrm{~m}^{-2}$ (expressed as a percentage of the total number of $30 \mathrm{yr}$ ) at each of the 15 sampling sites on Balgzand). Best fitting polynomial curve $\left(y=62+29 x-47 x^{2}, r^{2}=0.51, p=0.01\right)$ shown for $>10 m^{-2}$ as a criterion for successful recruitment. Sediment data are averages of the (few) late winter/early spring surveys available 


\section{Fishery disturbance and cockle recruitment}

$$
\text { Cockle Cerastoderma edule fishery }
$$

In the Dutch Wadden Sea, cockles are fished nowadays mostly by dredging: the upper bottom layer is loosened by strong spouts in front of a suction-dredge and several centimetres of the top layer passes through a $15 \mathrm{~mm}$ bar mesh cage. This reworking of the sediment results in an upper sediment layer with more shell fragments and lower mud contents (Piersma et al. 2001, Zwarts 2003). An annual average of $1.2 \%$ of the surface area of the tidal flats of the Dutch Wadden Sea is worked by cockle fishing gear (Ens et al. 2004). No exact data are available on this kind of bottom disturbance on Balgzand, but its impact may have been less than that of strong gales or serious ice scouring, which occurred at roughly similar frequencies. The cockle fishery on Balgzand was closed in 1993. Before closure, frequent observations of cockle-fishing ships, their fishing tracks and/or abnormally high mortality in adult cockles on Balgzand were almost restricted to a number of years in the 1978 to 1988 period at and around site 8 (Fig. 1a), where mud content in winter was usually around $1 \%$ (to increase to about $2 \%$ in summer) and cockle recruitment was frequently successful.

During the fishing period, mean values for relative recruitment (ratio fished/non-fished areas) were not lower than before fishing, nor was the mean ratio for the entire 'after'-period significantly lower than in any of the 2 earlier periods. Only the group of the last 4 yr (i.e. no less than a decade after the last fishing) showed significantly lower values than several earlier periods (Fig. 8a).
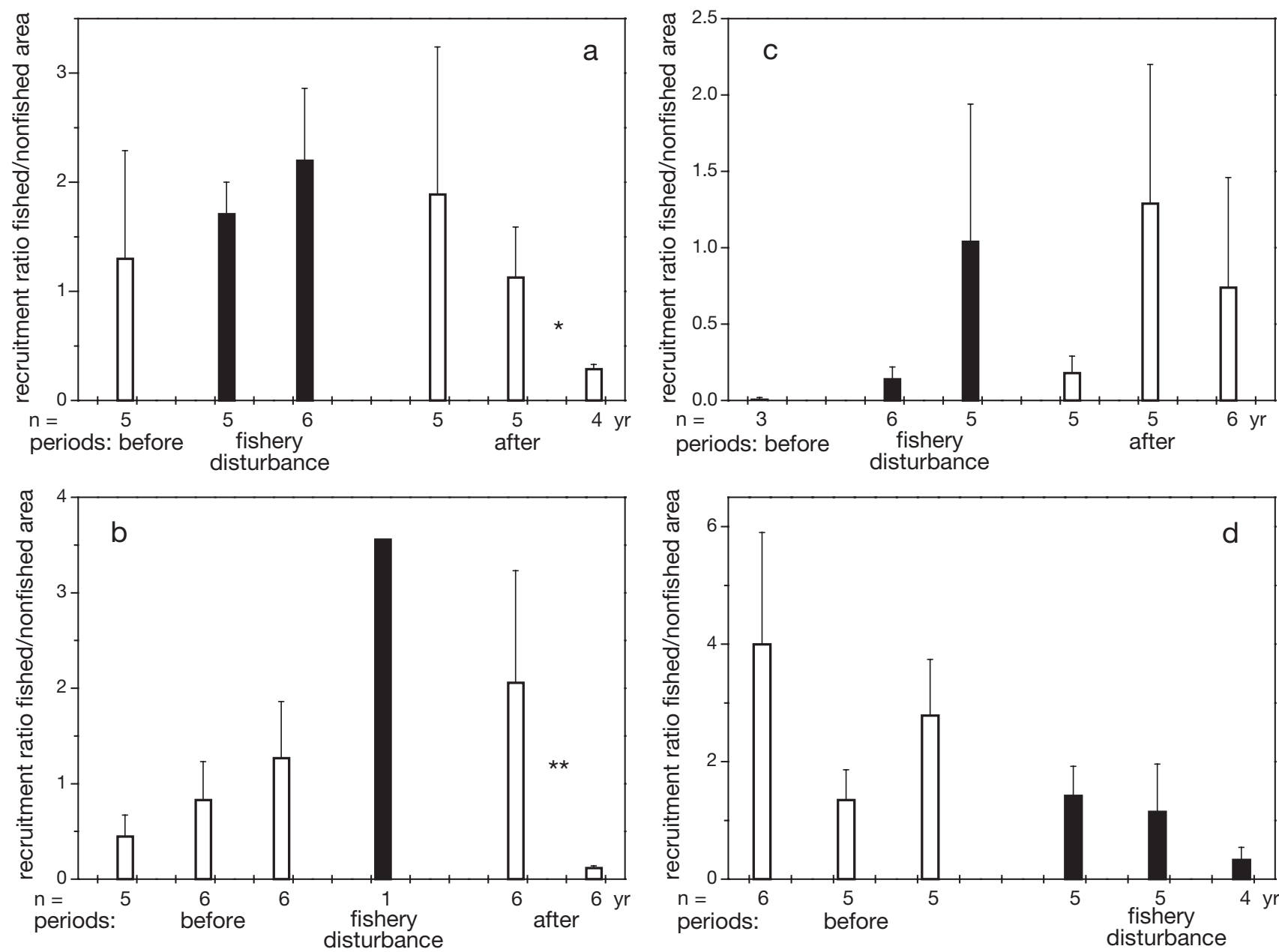

Fig. 8. Cerastoderma edule. Mean recruitment before, during and after a period of local fishery disturbance by (a) mechanical cockle dredging, (b) mussel fishery, and $(\mathrm{c}, \mathrm{d})$ lug worm dredging (c: first period, southern area; d: second period, northern area). See Fig. 1c for locations of fisheries. Length of periods (years) indicated on horizontal axis. Local recruitment values expressed as a ratio between recruitment in disturbance area (1 to 3 sampling sites) divided by mean recruitment in non-fished part of Balgzand (12 to 14 sites). Error bars indicate $1 \mathrm{SE}$ of means of 4 to 6 individual 1 yr values. Statistical significance of differences between means (neighbouring columns) evaluated by Mann-Whitney tests and indicated by $*(p<0.05)$ or $* *(p<0.01)$ 
Mussel Mytilus edulis fishery

Apart from small-scale mussel gatherings by hand, only one case of large-scale mechanical mussel fishery occurred on Balgzand. In the summer of 1990, a cockle-fishing boat removed all mussel beds in the area of our transects 4 and 5 (Fig. 1a), where mud contents varied between 2 and about $10 \%$ (depending on the distance from the mussel beds). Because of this fishing incident, the Balgzand area lost all of its mussel beds and the subsequent recovery of the former extensive beds was far from complete. Ratio values for cockle recruitment in the fished area for the first $6 \mathrm{yr}$ after this incident were not lower than before the fishing (Fig. 8b). For the second half of the 'after'-period (i.e. $>6$ yr after fishing), the ratio values were on average significantly lower than for the first half.

\section{Lug worm Arenicola marina fishery}

Apart from some hand digging at scattered places, fishing for lug worms on Balgzand is executed by 1 to 3 anchored pontoons, digging deep $(\sim 40 \mathrm{~cm})$ gullies, which remain visible for months (Beukema 1995). These dredging machines have been working on Balgzand every year since 1975. Intensive dredging took place from 1976 to about 1983 in the area around transect 6 (Fig. 1c), where mud contents were mostly 3 to $5 \%$. By the end of this period, lug worm densities in this area were reduced to low levels and fishermen started searching for more profitable areas east and northeast of this area. Sometimes, they were still observed near transect 6 , up to 1986 . The 1 st period (L-1 in Fig. 1c), near this transect, thus lasted from 1976 to 1986 , inclusive. Since 1989, fishing was regularly observed in the area of the transects-9, -10, and -11 (2nd period, L-2 in Fig. 1c), where mud contents were mostly around $2 \%$.

In the area of the first fishing period, no significant differences were found for cockle recruitment ratio values before, during and after the fishery disturbance (Fig. 8c). In the area of the second fishing period, cockle recruitment ratio values gradually declined during the fishing period and the average value for this $14 \mathrm{yr}$ period was significantly lower $(\mathrm{p}<0.02)$ than before this period (Fig. 8d). Note that substantially lower recruitment occurred no earlier than a decade after the start of fishing and that at this time (around 2000) cockle recruitment was relatively low in all offshore areas (Fig. 2a).

\section{The increasing cockle recruitment in near-shore areas}

The 3 sampling sites at $<1 \mathrm{~km}$ from the SW coast of Balgzand showed a time pattern of annual cockle recruitment differing from all other areas: numbers of recruits per $\mathrm{m}^{2}$ increased significantly (Table 1 ) rather than declining in the course of the period of observation. Particularly in the years after 1991, cockle recruitment in this near-shore area was often as successful as in the other parts of Balgzand, whereas it had been invariably less successful in the years before 1990 .

The increasing recruitment success in the near-shore area was probably not related to either the changes in shrimp abundance or the sediment composition. Shrimp abundance continued to increase (though at a low level in this area) and mud content will have been slightly higher there in the 1990s than in earlier decades. At mud contents of $>5 \%$, a decline (rather than an increase) of cockle recruitment is expected as a consequence of the increasing mud content (Fig. 7). The most conspicuous other change that took place in the near-shore area in the early 1990s was the crash of the population of the amphipod Corophium volutator. In this area, it was extremely numerous (usually several thousands $\mathrm{m}^{-2}$ ) in the 1970 s and $1980 \mathrm{~s}$, but suddenly its numbers declined to some tens $\mathrm{m}^{-2}$ in the early 1990s (as they did in the Danish Wadden Sea at that time, and this was possibly likewise caused by high winter temperatures, cf. Jensen \& Mouritzen 1992), to remain, for this species at a rather low level of $\sim 1000 \mathrm{~m}^{-2}$ in the second half of the 1990s (Fig. 9, white columns). Note that the increase of cockle recruit densities (black columns in Fig. 9) more or less coincided with the decline of Corophium densities: the 4 succes-

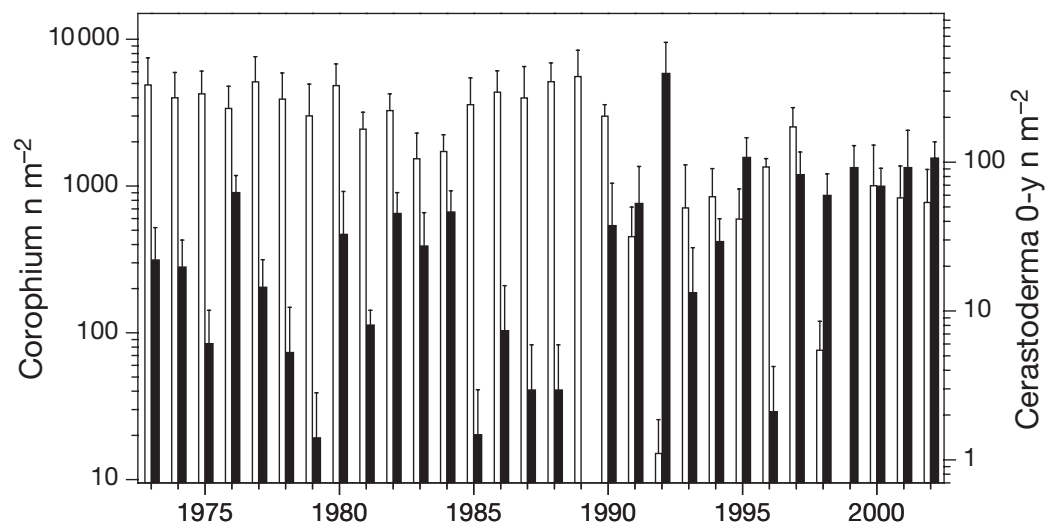

Fig. 9. Cerastoderma edule and Corophium volutator. Time course during the 1973 to 2002 period of (black columns) annual recruitment $\left(\mathrm{n} \mathrm{m}^{-2}\right.$ ) of cockles $C$. edule and of (white columns) abundance (mean of numerical density in March and August) of $C$. volutator within the near-shore area where the distribution of the 2 species overlap (site A and lower parts of transects 1 and 2, see Fig. 1a). Error bars indicate $1 \mathrm{SE}$ with $\mathrm{n}=3$ (the 3 sites) 
sive years of 1989 up to and including 1992. Over the entire 30 yr period, the numbers of cockle recruits and Corophium in the coastal zone where the distributions of the 2 species overlap were significantly negatively correlated $(\mathrm{r}=-0.61, \mathrm{n}=30, \mathrm{p}<0.01$, Spearman rank correlation).

\section{DISCUSSION}

\section{Long-term changes of recruitment success on Balgzand and elsewhere}

In all 3 species studied on Balgzand, we found similar long-term (1973 to 2002) trends: (1) a substantial and significant decline of overall recruitment success (top line of Table 2) and (2) a declining proportion of the recruits in the offshore half of the area (Fig. 3). The latter decline was non-significant in Macoma balthica, but in this species, offshore areas were always of minor significance as compared to the other 2 species (Figs. 3 \& 4). In Cerastoderma edule and Mya arenaria the proportional decline was caused mainly by a steeper longterm recruitment decline in offshore than in coastal areas (Table 2), where recruit densities were even about 7 times higher in the first half than in the second of the 1973 to 2002 period (Table 2). In C. edule the shoreward shift resulted also partly from increasing numbers in the near-shore (0 to $1 \mathrm{~km}$ ) zone (Tables 1 \& 2, Fig. 9). However, the contribution of the near-shore zone was small because of its relatively small size ( $15 \%$ of the Balgzand area) and mostly low cockle recruit densities. There is no obvious explanation for the increasing cockle recruitment in near-shore areas (during a period of increasing shrimp abundance), but it might have to do with the simultaneous decline in a numerically dominant species, Corophium volutator (Fig. 9).

As a consequence of the strongly declining recruit densities in offshore areas in the studied species, the centres of distribution of recruits shifted into a shoreward direction in the course of the study period. Note that in all 3 species a successful recruitment was present only in years when the centres of spat distribution were located at relatively long distances from the shore (Fig. 4).

In other parts of the Wadden Sea, changes similar to those on Balgzand were observed. Strasser et al. (2003) compared several long-term series on recruitment in the eastern part of the Dutch Wadden Sea (Groningen), and in the German (Norderney) and Danish (Ho Bay) Wadden Sea. Particularly in the cockle, annual recruit numbers $\mathrm{m}^{-2}$ were lower in the 1990s than in the preceding 1 or 2 decades. Neither was the shoreward shift of the annual centres of recruit distribution limited to the Balgzand area. At a group of sampling sites in the eastern part of the Dutch Wadden Sea (Groningen, cf. Essink 1978, Beukema et al. 1996), the proportion of cockle recruits found at the most offshore sites showed a significantly declining trend in the 1969 to 2002 period (K. Essink pers. comm. 2004). Over the entire Dutch Wadden Sea, the mean distance of cockle beds from the shore declined in the course of the 1975 to 2002 period (Fig. 7.1 of Zwarts 2003, Fig. 38 of Ens et al. 2004), their intertidal level became higher and their sediment muddier, as shown in Figs. 7.18 \& 7.19, respectively, of Zwarts (2003). The graphs by Zwarts suggest that an abrupt change took place around 1990 in the position of the cockle beds. The other major shift that took place on the tidal flats of the Dutch Wadden Sea in 1990 was the disappearance of virtually all intertidal mussel beds (and most cockle beds) by intensive fishing at low stocks, which will be discussed below.

On Balgzand, clear indications of an abrupt change around 1990 in neither the magnitude of recruitment (Fig. 2) nor its distribution over the area (Fig. 3) were observed. If anything, major shifts started already in 1988: this year was the first of a 3 yr series characterised by low recruitment success (Fig. 2) and low proportions of total recruitment in the offshore half of Balgzand (Fig. 3) in all 3 studied species. The timing of the major shift thus points to climate change rather than to sediment change as a causative factor governing the underlying processes leading to changed recruitment.

\section{Possible causes of long-term changes in bivalve recruitment success}

The above parallel changes (Table 2) in the 3 bivalve species point to a common controlling mechanism. Apparently, conditions for successful settlement (giving rise to high recruit numbers) became worse during the last decades, especially in offshore tidal-flat areas, thus preventing the development of strong cohorts in the Wadden Sea. In the Dutch Wadden Sea, 2 longterm changes comply with the condition that they could negatively affect bivalve recruitment, particularly at lower offshore tidal flats: (1) increases of shrimp abundance, because shrimp biomass is particularly high at low offshore tidal flats (Fig. 5) and (2) decline of mud content of the sediment in exposed offshore areas which are poor in mud: in the 1990s offshore tidal flats were on average less muddy and coastal tidal flats muddier than in the 1950s, as shown by Zwarts (2003, Fig. 5.9) and Ens et al. (2004). Such further declines of already low mud contents (as prevail at offshore tidal flats) would result in a reduced chance of a successful recruitment (Fig. 7). 


\section{Predation by shrimp and recruitment success}

In the last 2 or 3 decades, biomass values of shrimps roughly doubled on the tidal flats in March, April and May (Table 3). Because of the presence of a long-term trend of increasing water temperatures in spring, their food intake (and thus predation pressure) may have increased even more than their biomass. The observed negative relationships between shrimp abundance and subsequent (August) recruit densities of bivalves (Table 4), confirm earlier observations on Balgzand populations of Macoma balthica by Beukema et al. (1998) and Philippart et al. (2003) that shrimp can exert a decisive influence on recruitment success in this species and that May to June abundance of shrimps is the key factor. In the present paper, we show that this negative predator-prey relationship was significant in all 3 studied bivalve species for the May shrimp biomass estimates, and in 2 species for June estimates (Table 4) as well. The earlier end of the period of significant relationships in M. balthica will have to do with the earlier settlement of their postlarvae as compared to the 2 other species (see: Results: Assessment of relevant season).

In all seasons, shrimp biomass increased from high to low tidal flats (Fig. 5), and therefore from coastal to offshore tidal flats, as also observed by Beukema (1993) and Hiddink et al. (2002). Mean length of shrimps also increased in this direction. Thus, at the low offshore tidal flats, not only are bivalve recruits exposed to more severe predation pressure (by higher shrimp biomass and longer daily immersion periods), but this predation may also last longer before recruits have outgrown the size class that is vulnerable to shrimp predation.

If the abundance of shrimps is an important causative factor in the year-to-year variability of recruitment success of bivalves, then relationships between shrimp abundance and subsequent recruitment should be clearer where shrimps used to be abundant, i.e. in offshore areas as opposed to near-shore areas. A stronger long-term decline in recruitment may therefore be expected where the negative relationship between shrimp biomass and subsequent recruitment was stronger. Indeed, we observed a stronger decline in annual recruitment both in Macoma balthica (Fig. 6a) and in Cerastoderma edule (Fig. 6b) at sampling sites where the r-values for the correlation between shrimp biomass and subsequent bivalve recruitment were more negative. At near-shore sites, r-values were less negative (or even slightly positive) and long-term declines in recruitment were lower (or had even reversed to increases, as in cockles, Fig. 6b). Thus, not only the temporal (year-toyear) but also the spatial variation in bivalve recruitment success may be related to differential shrimp abundance.

As far as we are aware, no specific studies have been published on the possible causes of the recent increase in shrimp abundance; however, the increased frequency of mild winters in the last $15 \mathrm{yr}$ may have contributed. In cold winters, shrimps migrate further out of the Wadden Sea into the North Sea as compared to mild winters (Boddeke 1976). In the North Sea, they become fully exposed to such shrimp-consuming fish species as dab, gurnard and various gadoids, which are generally less numerous in the Wadden Sea (a notable exception was the mass invasion into the Wadden Sea of whiting in 1990, resulting in a temporary strong reduction of Wadden Sea shrimp stocks by early 1991, i.e. after a 'normal' winter, cf. Berghahn 1996). Moreover, the North Sea stocks of gadoids are declining due to over-fishing. Simultaneously, fishing effort on shrimps declined during the last decade to keep prices at an economic level by restriction of weekly landings, leaving more adult shrimp alive. This may have been a major cause of the exceptionally strong increase in the number of large shrimps caught in the tidal inlet in the 1990s (Table 3). Climatic changes may not have been the only cause of the increased shrimp abundance and the described year-to-year variation in predation pressure by shrimps may not have been entirely 'natural'.

\section{Sediment composition and recruitment success}

On the base of the bell-shaped curve depicted in Fig. 7, a decline of the frequency of occurrence of successful recruitment events may be expected if mud content declines in areas where the sediments contains $<\sim 1 \%$ mud. The recent shore-directed shift of mud in the Dutch Wadden Sea (more mud in coastal areas and less in offshore areas) described by Zwarts (2003) would then result in worsening recruitment conditions only in exposed offshore areas with invariably low mud contents. On Balgzand, only the 2 sampling sites located farthest offshore (12 and C in Fig. 1a) would be affected. At these 2 sites, cockle recruitment declined stronger than at any other site (Table 1). However, there are several other Balgzand sites (where mud contents much exceeded 1\%) that nevertheless showed a significant decline in recruitment trends (Table 1). In other parts of the international Wadden Sea, the observed recruitment declines were not restricted to areas with very low mud contents either (Strasser et al. 2003).

A shift to a coarser sediment with a lower content of fine material can arise from various causes, such as increased erosion or the disappearance of mussel beds. By their production of biodeposits, mussels and cockles add a huge amount of muddy material on sandy tidal flats within and around their beds (Oost 1995), giving rise to enhanced contents of mud (Zwarts 2003) and 
organic matter (Kröncke 1996) in the sediments up to $\sim 1 \mathrm{~km}$ from the beds. A major shift took place in and around 1990, when shellfish fishery was unusually intense and nearly all mussel beds (and most cockle beds) were removed from the Dutch Wadden Sea tidal flats (Dankers \& Zuidema 1995, Beukema \& Cadée 1996, Dankers et al. 2003). The formerly extensive mussel beds started to reappear in the Dutch Wadden Sea only in 1995, but have up to now barely recovered in its western half (Dankers et al. 2003, Ens et al. 2004). This may be the primary reason why in extensive offshore areas the sediments contained less mud (and probably also less organic matter) in the 1990s than in earlier decades, particularly in the western half of the Dutch Wadden Sea. In the offshore part of this area, where sediments have always been poor in mud because of their exposed position, the removal of all mussel beds made sediment composition even more extreme and thus may have turned at that time to sediments that were unsuitable for successful cockle recruitment for only this reason (Fig. 7).

Sediment disturbance by cockle fishing (which took place mostly in offshore areas before 1991) may also have contributed to this change to coarser sediments in offshore parts of the Wadden Sea (Piersma et al. 2001, Zwarts 2003). In the low-mud ( 1\%) area studied by Piersma et al. (2001), it took several years before the sediment had returned to its pre-fishing composition, but Zwarts (2003, Fig. 3.5) reports that in another (muddier) Wadden Sea tidal-flat area this was already so within 1 yr. Thus, fisheries for both cockles and mussels temporarily reduce mud content of the sediment and will retard its recovery by removing or thinning cockle and mussel beds. Repeated fishing may keep affected sandy areas (which are much more extensive than the actual former shellfish beds) in a state of too low mud content to allow good bivalve recruitment for a long period.

The actual evidence that sediment coarsening from cockle dredging has indeed resulted in lower bivalve recruitment is not unequivocal. This lack of consistency was to be expected from the relationship shown in Fig. 7, as most studies were executed in areas with mud contents of $>1 \%$ and results of these studies were not presented separately for areas with different sediment characteristics. The results of Piersma et al. (2001) appear to be most relevant. They followed mud content and recruitment for a long period after cockle dredging in an area with low mud content. Their results point to a reduced mud content and reduced recruitment of cockles and other bivalves for several years, specifically in areas where mechanical dredging for cockles had taken place. Studies by Leopold et al. (2003) and Kamermans et al. (2004), who compared recruitment in fished and non-fished parts of the Dutch
Wadden Sea, concern areas with a wide variety of sediment types and do not lead to clear conclusions. In studies on a very small scale (where sediments will be similar all over the studied area), this objection is less important. In a small non-fished area surrounded by a large fished area, with mud contents well above $1 \%$, Hiddink (2003) hardly found significantly differing densities of juvenile cockles and Macoma balthica (sometimes, spat densities were even higher in the fished area). Our own results (Fig. 8) also match with the expectation that at mud contents of $>1$ to $2 \%$ little influence of fishing on recruitment is to be expected. Although these activities will have reduced mud contents, none of these declines will have led to the extremely low mud levels where cockle recruitment is impaired according to Fig. 7 .

Summarizing, evidence of negative effects of dredging-caused loss of fine sediment components on cockle recruitment appears to be confined to the results reported by Piersma et al. (2001). Unfortunately, it is also the only study from which appropriate results and conclusions could be expected, as it is also the only long-term study that was made predominantly in an area with sediments sufficiently poor in mud where such negative effects are to be expected on the base of Fig. 7. Of course, it should be added that its mud content and coarseness are not necessarily the only properties of sediment that change at dredging operations and might make it less suitable for bivalve recruitment. Generally, higher mud contents go with higher contents of organic material. Such enriched sediments harbour a fauna very different from the surrounding 'bare' sand flats (Kröncke 1996). Although the surrounding areas that are enriched by shellfish banks may be extensive, it still remains to be proven that the (almost complete) disappearance of these banks around 1990 and the continued fishery for cockles in most of the subsequent years were the primary cause of the low bivalve recruitment after 1990 over the entire area of the Wadden Sea.

\section{Recruitment in near-shore areas and its consequences}

In years with low recruitment, centres of recruit distribution were located at short distances from the coast (Fig. 4): numbers of recruits were not only low, they were also to a large degree restricted to the zone close to the shore. Apparently, in these years with unfavorable conditions for recruitment (generally high shrimp abundance), the high mudflats of the coastal zone constituted a relatively safe refuge for all 3 bivalve species. Contrary to this view, Reise (1987) concluded, from a study of the distribution of small and juvenile 
macrozoobenthos over an extensive tidal-flat area in the North Friesian Wadden Sea, that there was no particular sub-region of higher importance to juveniles. Among the bivalves he studied, only Macoma balthica spat showed maximal densities in coastal areas, whereas the spat of Cerastoderma edule and Mya arenaria were most abundant on seaward, lower-level flats. Reise's studies happened to be performed in 1979, a year with exceptionally successful recruitment of bivalves all over the Wadden Sea (Beukema et al. 1996, 2001a). This means that the results of Reise $(1987)$ are in fact similar to ours: at high recruit densities, areas of high density are located at long distances from the shore (Fig. 4), but in M. balthica this distance is shorter (Fig. 4c) than in the 2 other species (Fig. 4a,b). We speculate that if Reise had made his observations in a year with low recruitment, he would have found maximal densities of all bivalve juveniles close to the coast and might have stressed the importance of a coastal refuge for all bivalve species.

Not only do the observed long-term trends of lower and more shore-bound annual recruitment lead to adult populations of a smaller size (Van der Meer et al. 2001), but also there is a quality aspect. Coastal populations at higher intertidal levels (with shorter immersion times) generally show reduced growth rates (e.g. cockles, Jensen 1992, Macoma balthica, Beukema 1993), resulting in smaller adults with lower soft-tissue weights at a certain shell size, producing fewer and smaller eggs (Van der Meer et al. 2003). In near-shore bivalve populations, higher mortality rates by lower condition (Beukema et al. 2001b), enhanced predation pressure by wading birds, parasite loads (Lim \& Green 1991) and more extreme environmental conditions (Beukema 1985) lead to lower lifetime egg production (Van der Meer et al. 2003). At an evolutionary time scale, the appropriate adaptive response to a forced start of benthic life in coastal refuges that are sub-optimal for the adult life stage would be an offshore migration once the juveniles have reached a size that makes them less vulnerable to most aquatic predators. Among the bivalves of the Wadden Sea, only M. balthica appears to have developed such offshore migratory behaviour after the first growing season (Beukema \& De Vlas 1989, Beukema 1993, Hiddink \& Wolff 2002, Beukema \& Dekker 2003). Several other species are also able to perform byssus-drift, but this appears to be limited to their early postlarval stages (Armonies 1994).

\section{CONCLUSIONS}

The recent decline of recruitment success in some important bivalve species in the Wadden Sea, accompanied by a shoreward shift of their centres of distrib- ution, may be explained by an increasing predation pressure by aquatic predators, such as shrimps, on newly settled postlarvae. Increased predation from such predators would be most serious at the lower offshore tidal flats and would thus bring about 2 simultaneous effects: (1) reduction of total recruitment and (2) forcing it back to high-level near-shore refuges. Shrimp abundance in spring on tidal flats is climate related (Beukema 1992a), and this may (at least partly) explain why bivalve recruitment is so often failing after a mild winter and why it shows a declining trend over recent decades and particularly so at low tidal flats.

Deteriorating sedimentary conditions at offshore tidal flats might be an alternative explanation of the observed declining recruitment success. The 2 possible explanations are not mutually exclusive, but one wonders which is most generally applicable and important.

In the offshore parts of the western half of the Dutch Wadden Sea, a decline of mud content of the sediments took place recently over extensive areas, maybe mainly because of the removal of all mussel beds in and around 1990 and/or intensive dredging for cockles. Although we could not assess any direct effects of bottom-disturbing fisheries on cockle recruitment in the fished areas on Balgzand, negative effects may have been present in more exposed areas with sediments characterized by very low mud content and where sediment composition may be crucial and any decline in content of fine material may make the bottom less suitable for bivalve recruitment. Such extremely mud-poor sediments occur on Balgzand only in a small offshore part that is much smaller than the area where we actually observed substantial declines of recruitment. Moreover, the timing (start in 1988) of the changes in recruitment magnitude and distribution pattern in all 3 species coincided with the start of the change in climate regime (1988) rather than with the start of major sediment changes (1990). Therefore, we think that an explanation on the base of increased epibenthic predation (and ultimately on climate change) may be more probable and general than one based on changes in sediment composition. This choice for a predation mechanism is supported by the fact that the recent decline of bivalve recruitment (and its shoreward shift to higher and muddier tidal flats) is not restricted to the western half of the Dutch Wadden Sea (Strasser et al. 2003). The geographically large scale of the events points to climate-related factors as opposed to local man-induced factors (Beukema et al. 1996). Increased shrimp predation, therefore, may be the predominating mechanism for the described phenomena (cf. Philippart et al. 2003 for a similar conclusion regarding $M$. balthica recruitment). If climate factors were the main factor governing year class strength in Wadden Sea bivalves, the declining trend of bivalve 
stocks will continue as long as the expected global warming continues. Then years with food shortage for shellfish eating birds and severe competition with fishery will be frequent. In this scenario, mechanical cockle fishery will continue to be harmful, even in the case where this fishery does not directly harm recruitment.

Acknowledgements. This study is part of a long-term monitoring program on macrozoobenthos in the Wadden Sea and was financially supported by the Dutch National Institute for Coastal and Marine Management (RWS/RIKZ). We thank NIOZ colleagues, in particular T. Piersma, for their comments on earlier versions of this paper.

\section{LITERATURE CITED}

Armonies W (1994) Drifting meio- and macrobenthic invertebrates on tidal flats in Königshafen: a review. Helgol Meeresunters 48:299-320

Atkinson PhW, Clark NA, Bell MC, Dare PJ, Clark JA, Ireland $\mathrm{PhL}$ (2003) Changes in commercially fished shellfish stocks and shorebird populations in the Wash, England. Biol Conserv 114:127-141

Bachelet G (1986) Recruitment and year-to-year variability in a population of Macoma balthica (L.). Hydrobiologia 142: 233-248

Berghahn R (1996) Episodic mass invasions of juvenile gadoids into the Wadden Sea and their consequences for the population dynamics of brown shrimp (Crangon crangon). PSZN I: Mar Ecol 17:251-260

Beukema JJ (1982) Annual variation in reproductive success and biomass of the major macrozoobenthic species living in a tidal flat area of the Wadden Sea. Neth J Sea Res 16: $37-45$

Beukema JJ (1985) Zoobenthos survival during severe winters on high and low tidal flats in the Dutch Wadden Sea. In: Gray JS, Christiansen ME (eds) Marine biology of polar regions and effects of stress on marine organisms. John Wiley, Chichester, p 351-361

Beukema JJ (1988) An evaluation of the ABC-method (abundance/biomass comparison) as applied to macrozoobenthic communities living on tidal flats in the Dutch Wadden Sea. Mar Biol 99:425-433

Beukema JJ (1991) The abundance of shore crabs Carcinus maenas (L.) on a tidal flat in the Wadden Sea after cold and mild winters. J Exp Mar Biol Ecol 153:97-113

Beukema JJ (1992a) Dynamics of juvenile shrimp Crangon crangon in a tidal-flat nursery of the Wadden Sea after mild and cold winters. Mar Ecol Prog Ser 83:157-165

Beukema JJ (1992b) Expected changes in the Wadden Sea benthos in a warmer world: lessons from periods with mild winters. Neth J Sea Res 30:73-79

Beukema JJ (1993) Successive changes in distribution patterns as an adaptive strategy in the bivalve Macoma balthica (L.) in the Wadden Sea. Helgol Meeresunters 47: 287-304

Beukema JJ (1995) Long-term effects of mechanical harvesting of lugworms Arenicola marina on the zoobenthic community of a tidal flat in the Wadden Sea. Neth J Sea Res $33: 219-227$

Beukema JJ, Cadée GC (1996) Consequences of the sudden removal of nearly all mussels and cockles from the Dutch Wadden Sea. PSZN I: Mar Ecol 17:279-289

Beukema JJ, Cadée GC (1999) An estimate of the sustainable rate of shell extraction from the Dutch Wadden Sea. J Appl Ecol 36:49-58

Beukema JJ, Dekker R (2003) Redistribution of spat-sized Macoma balthica in the Wadden Sea in cold and mild winters. Mar Ecol Prog Ser 265:117-122

Beukema JJ, De Vlas J (1989) Tidal-current transport of thread-drifting postlarval juveniles of the bivalve Macoma balthica from the Wadden Sea to the North Sea. Mar Ecol Prog Ser 52:193-200

Beukema, JJ, Essink K, Michaelis H, Zwarts L (1993) Year-toyear variability in the biomass of macrozoobenthic animals on tidal flats of the Wadden Sea: how predictable is this food source for birds? Neth J Sea Res 31:319-330

Beukema JJ, Essink K, Michaelis H (1996) The geographic scale of synchronized fluctuation patterns in zoobenthos populations as a key to underlying factors: climatic or man-induced. ICES J Mar Sci 53:964-971

Beukema JJ, Honkoop PJC, Dekker R (1998) Recruitment in Macoma balthica after mild and cold winters and its possible control by egg production and shrimp predation. Hydrobiologia 375/376:23-34

Beukema JJ, Dekker R, Essink K, Michaelis H (2001a) Synchronized reproductive success of the main bivalve species in the Wadden Sea: causes and consequences. Mar Ecol Prog Ser 211:143-153

Beukema JJ, Drent J, Honkoop PJC (2001b) Maximising lifetime egg production in a Wadden Sea population of the tellinid bivalve Macoma balthica: a trade-off between immediate and future reproductive outputs. Mar Ecol Prog Ser 209:119-129

Boddeke R (1976) The seasonal migration of the brown shrimp Crangon crangon. Neth J Sea Res 10:103-130

Camphuysen CJ, Ens BJ, Heg D, Hulscher JB, Van der Meer J, Smit CJ (1996) Oystercatcher Haematopus ostralegus winter mortality in the Netherlands: the effect of severe weather and food supply. Ardea 84A:469-492

Camphuysen CJ, Berrevoets CM, Cremers HJWM, Dekinga A and 8 others (2002) Mass mortality of common eiders (Somateria mollissima) in the Dutch Wadden Sea, winter 1999/2000: starvation in a commercially exploited wetland of international importance. Biol Conserv 106:303-317

Coosen J, Twisk F, Van der Tol MWM, Lambeck RHD, Van Stralen MR, Meire PM (1994) Variability in stock assessment of cockles (Cerastoderma edule L.) in the Oosterschelde (in 1980-1990), in relation to environmental factors. Hydrobiologia 282/283:381-395

Dankers N, Zuidema DR (1995) The role of the mussel (Mytilus edulis L.) and mussel culture in the Dutch Wadden Sea. Estuaries 18(1A):71-80

Dankers NMJA, Meijboom A, Cremer JSM, Dijkman EM, Hermes Y, Te Marvelde L (2003) Historische ontwikkeling van droogvallende mosselbanken in de Nederlandse Waddenzee. Alterra Rapport 876, Alterra, Wageningen, $114 \mathrm{p}$

Desprez M, Bachelet G, Beukema JJ, Ducrotoy JP and 5 others (1991) Dynamique des populations de Macoma balthica (L.) dans les estuaires du Nord-Ouest de l'Europe: première synthèse. In: Elliott $M$, Ducrotoy JP (eds) Estuaries and coasts: spatial and temporal intercomparisons. Olsen \& Olsen, Fredensborg, p 159-166

Ducrotoy JP, Rybarczyk H, Souprayen J, Bachelet G and 10 others (1991) A comparison of the population dynamics of the cockle (Cerastoderma edule, L.) in North-Western Europe. In: Elliott M, Ducrotoy JP (eds) Estuaries and coasts: spatial and temporal intercomparisons. Olsen \& Olsen, Fredensborg, p 173-184

Ens BJ (2003) What we know and what we should know about 
mollusc fisheries and aquacultures in the Wadden Sea. In: Wolff WJ et al. (eds) Challenges to the Wadden Sea area. Proc 10th Int Sci Wadden Sea Symp, Ministry of Agriculture, Groningen, p 121-146

Ens BJ, Smaal AC, De Vlas J (2004) The effects of shellfish fishery on the ecosystems of the Dutch Wadden Sea and Oosterschelde. Final report on the second phase of the scientific evaluation of the Dutch shellfish fishery policy (EVA II). Alterra Rapport 1011, RIVO rapport C056/04, RIKZ-rapport RKZ/2004.031, Alterra, Wageningen

Essink K (1978) The effects of pollution by organic waste on macrofauna in the eastern Dutch Wadden Sea. Neth Inst Sea Res Publ Ser 1:1-135

Flach EC (2003) The separate and combined effects of epibenthic predation and presence of macro-infauna on the recruitment success of bivalves in shallow soft-bottom areas on the Swedish west coast. J Sea Res 49:59-67

Gosselin LA, Quian PY (1997) Juvenile mortality in benthic marine invertebrates. Mar Ecol Prog Ser 146:265-282

Günther CP (1991) Settlement of Macoma balthica on an intertidal sandflat in the Wadden Sea. Mar Ecol Prog Ser 76:73-79

Günther CP (1992) Settlement and recruitment of Mya arenaria L. in the Wadden Sea. J Exp Mar Biol Ecol 159:203-215

Hiddink JG (2003) Effects of suction-dredging for cockles on non-target fauna in the Wadden Sea. J Sea Res 50: 315-323

Hiddink JG, Wolff WJ (2002) Changes in distribution and decrease in numbers during migration of the bivalve Macoma balthica. Mar Ecol Prog Ser 233:117-130

Hiddink JG, Marijnissen SAE, Troost K, Wolff WJ (2002) Predation on 0-group and older year classes of the bivalve Macoma balthica: interaction of size selection and intertidal distribution of epibenthic predators. J Exp Mar Biol Ecol 269:233-248

Holland AF, Mountford NK, Hiegel MH, Kaumeyer KR, Mihursky JA (1980) Influence of predation on infaunal abundance in Upper Chesapeake Bay, USA. Mar Biol 57: 221-235

Honkoop PJC, Van der Meer J, Beukema JJ, Kwast D (1998) Does temperature-influenced egg production predict the recruitment in the bivalve Macoma balthica? Mar Ecol Prog Ser 164:229-235

Hunt HL, Mullineaux LS (2002) The roles of predation and postlarval transport in recruitment of the soft shell clam (Mya arenaria). Limnol Oceanogr 47:151-164

Jensen KT (1992) Dynamics and growth of the cockle, Cerastoderma edule, on an intertidal mud-flat in the Danish Wadden Sea: effect of submersion time and density. Neth J Sea Res 28:335-345

Jensen KT, Mouritsen KN (1992) Mass mortality in 2 common soft-bottom invertebrates, Hydrobia ulvae and Corophium volutator - the possible role of trematodes. Helgol Meeresunters 46:329-339

Kamermans P, Bult T, Kater B, Baars D, Kesteloo J, Perdon J, Schuiling E (2004) Invloed van natuurlijke factoren en kokkelvisserij op de dynamiek van bestanden aan kokkels (Cerastoderma edule) en nonnen (Macoma balth$i c a)$ in de Waddenzee, Ooster- en Westerschelde. RIVO Rapport C058/03, Yerseke

Kröncke I (1996) Impact of biodeposition on macrofaunal communities in intertidal sandflats. PSZN I: Mar Ecol 17: 159-174

Leopold MF, Dijkman EM, Cremer JSM, Meijboom A (2003) De effecten van mechanische kokkelvisserij op de benthische macrofauna en hun habitat. Alterra Rapport 955, Wageningen
Lim SSL, Green, RH (1991) The relationship between parasite load, crawling behaviour, and growth rate of Macoma balthica (L.) (Mollusca, Pelecypoda) from Hudson Bay, Canada. Can J Zool 69:2202-2208

Mattila J, 'Olafsson EB, Johansson A (1990) Predation effects of Crangon crangon on benthic infauna on shallow sandy bottoms - an experimental study from southern Sweden. In: Barnes M, Gibson RN (eds) Trophic relationships in the marine environment. Proc 24th Eur Mar Biol Symp, Aberdeen Univ Press, p 503-516

Möller P (1986) Physical factors and biological interactions regulating infauna in shallow boreal areas. Mar Ecol Prog Ser 30:33-47

Möller P, Rosenberg R (1983) Recruitment, abundance and production of Mya arenaria and Cardium edule in marine shallow waters, western Sweden. Ophelia 22:33-55

Oost AP (1995) Dynamics and sedimentary development of the Dutch Wadden Sea with emphasis on the Friesian inlet. Geol Ultraiectina 126:1-455

Philippart CJM, Van Aken HM, Beukema JJ, Bos OG, Cadée GC, Dekker R (2003) Climate-related changes in recruitment of the bivalve Macoma balthica. Limnol Oceanogr 48:2171-2185

Piersma T, Koolhaas A, Dekinga A, Beukema JJ, Dekker R, Essink K (2001) Long-term indirect effects of mechanical cockle-dredging on intertidal bivalve stocks in the Wadden Sea. J Appl Ecol 38:976-990

Reise K (1985) Tidal flat ecology. An experimental approach to species interactions. Springer-Verlag, Berlin

Reise K (1987) Distribution and abundance of small and juvenile macrofauna on the tidal flats in the Friesian Wadden Sea. In: Tougaard S, Asbirk S (eds) Proc 5th Int Wadden Sea Symp. Nat Forest Nature Agency, Esbjerg, p 7-25

Richards MG, Huxham M, Bryant A (1999) Predation: a causal mechanism for variability in intertidal bivalve populations. J Exp Mar Biol Ecol 241:159-177

Sanchez-Salazar ME, Griffiths CL, Seed R (1987) The interactive roles of predation and tidal elevation in structuring populations of the edible cockle, Cerastoderma edule. Estuar Coast Shelf Sci 25:245-260

Smit CJ, Dankers N, Ens BJ, Meijboom A (1998) Birds, mussels, cockles and shellfish fishery in the Dutch Wadden Sea: how to deal with low food stocks for Eiders and Oystercatchers? Senckenb Marit 29:141-153

Spaargaren DH (2000) Seasonal and annual variations in the catches of Crangon crangon (L., 1758) (Decapoda, Natantia) near the coast of Texel, The Netherlands. Crustaceana 73:547-563

Strasser M (2002) Reduced epibenthic predation on intertidal bivalves after a severe winter in the European Wadden Sea. Mar Ecol Prog Ser 241:113-123

Strasser M, Günther CP (2001) Larval supply of predator and prey: temporal mismatch between crabs and bivalves after a severe winter in the Wadden Sea. J Sea Res 46:57-67

Strasser M, Hertlein A, Reise K (2001) Differential recruitment of bivalve species in the northern Wadden Sea after the severe winter of 1995/96 and of subsequent milder winters. Helgol Mar Res 55:182-189

Strasser M, Dekker R, Essink K, Günther CP and 6 others (2003) How predictable is high bivalve recruitment in the Wadden Sea after a severe winter? J Sea Res 49:47-57

Van Aken HM (2003) 140 years of daily observations in a tidal inlet (Marsdiep). ICES Mar Sci Symp 219:359-361

Van der Meer J, Beukema JJ, Dekker R (2001) Long-term variability in secondary production of an intertidal bivalve population is primarily a matter of recruitment variability. J Anim Ecol 70:159-169 
Van der Meer J, Beukema JJ, Dekker R (2003) Large spatial variability in lifetime egg production in an intertidal Baltic tellin (Macoma balthica) population. Helgol Mar Res 56: 274-278

Van der Veer HW, Witte JIJ, Beumkes HA, Dapper R, Jongejan WP, Van der Meer J (1992) Intertidal fish traps as a tool to study long-term trends in juvenile flatfish populations. Neth J Sea Res 29:119-126

Van der Veer HW, Feller RJ, Weber A, Witte JIJ (1998) Importance of predation by crustaceans upon bivalve spat in the intertidal zone of the Dutch Wadden Sea as revealed by

Editorial responsibility: Otto Kinne (Editor-in-Chief), Oldendorf/Luhe, Germany immunological assays of gut contents. J Exp Mar Biol Ecol 231:139-157

Young EF, Bigg GR, Grant A (1996) A statistical study of environmental influences on bivalve recruitment in the Wash, England. Mar Ecol Prog Ser 143:121-129

Ysebaert T, Meire P, Herman PMJ, Verbeek H (2002) Macrobenthic species response surfaces along estuarine gradients: prediction by logistic regression. Mar Ecol Prog Ser 225:79-95

Zwarts L (2003) Bodemgesteldheid en mechanische kokkelvisserij in de Waddenzee. RIZA Rapport, RIZA, Lelystad

Submitted: April 2, 2004; Accepted: August 12, 2004

Proofs received from author(s): February 3, 2005 